Savunma Bilimleri Dergisi

The Journal of Defense Sciences

Mayıs / May 2021, Say1/Issue 39.

ISSN (Bas1li) : 1303-6831 ISSN (Online): 2148-1776

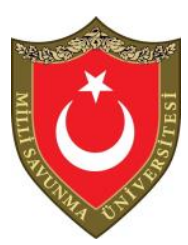

\title{
Hipersonik Füzeler ve Stratejik İstikrar: Rusya-ABD İlişkileri Üzerine Bir İnceleme
}

\author{
Eray ALIM*
}

$\ddot{O} z$

Hiz ve yüksek manevra yeteneği gibi özellikleriyle hipersonik füzeler, devletler arasındaki askerî güç dengesini önemli şekilde etkileyebilecek silahlardır. Savunma ve güvenlik eksenli olarak öngörülemezlik riskini arttırmalarından dolayı hipersonik füzelerin stratejik sonuçlar doğurması azımsanmaması gereken bir ihtimaldir. Bu silahların özellikle büyük güçlerin envanterine girmeye başlaması, hipersonik füzelerin askerî güç dengesi üzerindeki olası etkilerine dair bir projeksiyon yapmayı gerekli kilmaktadır. Bu tespitten hareketle bu çalışma, Rusya ve Amerika Birleşik Devletleri (ABD) arasındaki stratejik denge üzerinde hipersonik füzelerin olası etkilerini incelemektedir. Bu iki ülke arasindaki ilişsiye odaklanmanın iki temel nedeni vardır. Illk olarak, yöntemsel bir açıdan bakıldığında, hipersonik füzelerin etkisini ölçmek için, bu silahların konvansiyonel veya nükleer başlık taşımaları durumunda nasıl etkiler yaratabileceğinin cevapları gereklidir. Bunun için, iki farklı vaka incelemesine ihtiyaç vardır. Rusya nükleer, $A B D$ ise konvansiyonel vuruş kapasitesini geliştirmek için hipersonik füzelere yatırım yaptı̆̆ için, bu iki ülkenin birbirleriyle olan rekabetinde bu silahların kullanım amaçlarına bakılarak önemli ampirik çıkarsamalara ulaşılabilecektir. İkinci olarak, "büyük güç rekabeti" bağlamında tematik bir açıdan bakıldı̆̆ında, hipersonik füzelerin Rusya-ABD ilişkilerine dönük olası etkileri incelenerek, uluslararası güvenlik üzerinde bu silahların ne gibi yansımalarının olabileceğine dair bir bakış açısı sunulabilecektir.

* Dr. Öğr. Üyesi, Batman Üniversitesi, Siyaset Bilimi ve Kamu Yönetimi Bölümü, erayalim@ @otmail.com, ORCID: 0000-0001-7543-8021.

Geliş Tarihi/Received : 20.04.2020

Kabul Tarihi/Accepted : 27.10.2020

Araştırma Makalesi/Research Article DOI: 10.17134/khosbd.913731 
Anahtar Kelimeler: Hipersonik Füzeler, Hipersonik Silahlar, Rusya - Savunma, ABD - Savunma, Stratejik Istikrar, Nükleer Strateji, Konvansiyonel Strateji.

\title{
Hypersonic Missiles and Strategic Stability: An Analysis of Russia-US Relations
}

\begin{abstract}
Thanks to their speed and high maneuvering ability, hypersonic missiles qualify as weapons systems that can have a significant impact ipon the balance of military power among states. As these missiles enhance unpredictability in the realm of security and defense, they are highly likely to generate strategic consequences. Given the fact that especially great powers have begun to incorporate hypersonic missiles into their arsenal, it is necessary to examine the potential impacts of this development on the balance of military power. This article concerns itself with this issue and seeks to assess the likely effects of hypersonic missiles by focusing on the strategic balance between the US and Russia. The reason for selecting these two countries is twofold. First, in a methodological context, two different case studies are required to assess the likely impacts of hypersonic missiles, which may be armed with nuclear or conventional warheads. As Russia and the US intend to arm hypersonic missiles with nuclear and conventional warheads respectively, one would be able to draw the necessary empirical inferences by examining the military rivalry between these two states in the light of hypersonic missiles. Second, in a thematic context based on great power rivalry, by examining the likely effects of hypersonic missiles on Russia-US relations, one would be able to offer a perspective on the impact of these weapons on international security.
\end{abstract}

Keywords: Hypersonic Missiles, Hypersonic Weapons, Russia - Defense, the US Defense, Strategic Stability, Nuclear Strategy, Conventional Strategy.

Giriş

Devletlerin hipersonik füzelere artan bir ilgi göstermeye başlaması, bu silahların askerî güç dengesini nasıl etkileyebileceği sorusunu gündeme taşımıştır. Zira söz konusu füzeler, ses hızının en az beş katı bir hıza ulaşma kapasiteleriyle ve etkili manevra yetenekleriyle, hava unsurları arasında ayrıcalıklı bir konuma sahip olabilecektir. Bu bağlamda, yetkin ülke sayısı hâlihazırda sınırlı olsa da ABD, Rusya, Çin, Hindistan ve Fransa başta olmak üzere, askerî kapasite bakımından 
Hipersonik Füzeler ve Stratejik İstikrar:

Rusya-ABD İlişkileri Üzerine Bir İnceleme

başı çeken ülkeler hipersonik araçlar geliştirme çabalarını yoğunlaştırmaktadır (Speier vd., 2017). Başat askerî güçlerin hipersonik silahlara yatırım yapmaları, kaçınılmaz olarak bunun uluslararası istikrarı nasıl etkileyebileceğini önemli bir soru olarak ortaya çıkarmaktadır. Zira insanın algı yeteneğinin ötesinde bir hız kapasitesine sahip olan hipersonik unsurların öngörüsüz bir şekilde kullanılmaları durumunda, bunun riskli gelişmelere kapı aralaması kuvvetle muhtemeldir. $\mathrm{Bu}$ durum siyasetçilerin de gözünden kaçmamaktadır. Almanya Dışişleri Bakanı Heiko Maas'ın belirttiği gibi, sahip oldukları hız ve manevra kabiliyeti ile hipersonik füzeler, karşı tarafa neredeyse hiç zaman tanımayan unsurlardır. Yaşanan sürecin bir bilim-kurgu ürünü olmadığını ve gerçeklik hâlini aldığını vurgulayan Maas, 2019'da hizmete giren Rusya'nın Avangard füzesinin bunu doğruladığını ifade etmiştir (Federal Foreign Office, 2019).

Özellikle 2010'ların başından itibaren hipersonik füze denemelerini yoğunlaştıran devletler, 2010'ların sonuna doğru bu silahları envanterlerine dâhil etmeye başlamışlardır. Rusya'nın stratejik bir hipersonik füze olan Avangard'1, Çin'in ise hem stratejik hem taktik amaçlı kullanılabilecek DF-17 füzesini envanterine katması, bu alanda önemli başarılar olarak kayda geçmiştir (Barrie, 2019). $\mathrm{Bu}$ gelişmeler karşısında $\mathrm{ABD}$, rakiplerinin gerisinde kalmamak için hipersonik füze sistemleri geliştirme çabalarını güçlendirmeye başlamıştır. Hâlihazırda hipersonik teknoloji geliştirme konusunda ABD, Rusya ve Çin başı çeken ülkeler olsalar da Hindistan, Avustralya, Fransa, Japonya ve Almanya gibi ülkeler de bu alandaki çalışmalarını yoğunlaştırmaktadır. Bu çalışmalar devam ederken, hipersonik teknoloji konusunda yetkin ülkeler, yakın ilişki içinde oldukları ülkelere teknoloji desteği sunarak, üçüncü aktörlerin hipersonik sistemlere ulaşımını hızlandırmaktadır. Bu minvalde Avustralya'nın HIFIRE (Hypersonic International Flight Research Experimentation) projesine ABD'nin, Hindistan'ın BrahMos-II hipersonik seyir füzesi projesine ise Rusya'nın verdiği katkılar öne çıkmaktadır (Sayler, 2020: 16).

$\mathrm{Bu}$ gelişmeler neticesinde hipersonik füzeler devletler arasındaki askerî güç dengesini etkileyebilecek unsurlar olarak gün geçtikçe daha fazla belirginlik kazanmaktadır. Örneğin Hindistan'ın, hipersonik seyir füzesi BrahMos-II ile Pakistan ve Çin karşısında, Çin'in ise DF-17 füzesi ile ABD, Japonya ve Hindistan karşısında stratejik avantaj elde etmesi söz konusu olabilecektir (Barrie, 2019). Teknik bir açıdan hipersonik füzelerin etkisini irdelerken, bu unsurların 
etkinliklerinin yalnızca hız kapasitelerinden kaynaklanmadığı ve güçlü manevra kabiliyetlerinin, alçak irtifadan uçabilmelerinin ve hedef isabeti konusundaki yetkinliklerinin de bu silahlara önemli avantajlar sağladığı kaydedilmelidir. Bazı görüşlere göre bu özellikleriyle hipersonik sistemler, askerî rekabette niteliksel bir dönüşüme neden olacak unsurlardır (Simon, 2020; The Economist, 2020). Bazı uzmanlar daha ihtiyatlı bir yaklaşıma sahip olsalar da (Oelrich, 2020; Kofman, 2019) söz konusu silahların bölgesel ve/veya küresel güvenlik alanında yansımalarının olacağı ve devletlerarası askerî rekabete bir etken olarak ekleneceği muhakkaktır.

Hipersonik füzelerin devletlerarası ilişkiler üzerindeki potansiyel etkilerini ölçmek için, öncelikli olarak yöntemsel bir izahata ihtiyaç vardır. Söz konusu füzelerin askerî güç dengesine nasıl tesir edeceği ve bunun uluslararası güvenlik üzerinde nasıl etkiler yaratacağına anlamlı cevaplar üretebilmek için, bu füzeleri devletlerin hangi amaçlarla geliştirmek istedikleri mercek altına alınmalıdır. Hipersonik füzeler, birçok seyir füzesi ve balistik füze gibi, konvansiyonel ya da nükleer başlık taşıyabilme yeteneğine sahiptir. Taktik ya da stratejik amaçlı kullanıma bağlı olarak bu füzeler muhtelif rekabet alanlarında farklı amaçlarla kullanılabilecektir. Örneğin, nükleer vuruş kabiliyetini güçlendirmek isteyen ülkeler ile nükleer olmayan vuruş kapasitesini geliştirmek isteyen ülkeler için hipersonik füzeler farklı işlevselliklere sahiptir. Bu bağlamda söz konusu füzelerin, konvansiyonel ve nükleer başlıklarla donatıldıklarında nasıl etkiler yaratabileceğinin ayrı vaka incelemeleri üzerinden ele alınması gerekmektedir.

$\mathrm{Bu}$ incelemeleri gerçekleştirmeye çalışan bu çalışma hipersonik füzelerin etkisini sorgularken, Rusya-ABD ilişkisine odaklanılacaktır. Rusya, hipersonik silahları nükleer vuruş kabiliyetini güçlendirmek için geliştirirken, $\mathrm{ABD}$, konvansiyonel vuruş kapasitesini arttırmak için bu silahlara yatırım yapmaktadır. Hâlihazırda bu iki ülke arasında askerî bir rekabet yaşanmakta olduğu için, bu rekabeti hipersonik füzelerin ışığında değerlendirerek, bu silahların yaratabileceği olası etkilere dair faydalı bir perspektif sunulabilecektir. Diğer taraftan söz konusu füzelerin, iki önemli askerî güç olan $\mathrm{ABD}$ ve Rusya arasındaki stratejik dengeye nasıl tesir edeceğine bakarak, bu silahların uluslararası istikrar üzerindeki etkisine dair aydınlatıcı bir bakış açısı da sunulabilecektir. Kavramsal çerçeveyi netleştirmek amacıyla, bu çalışmada hipersonik füzelerden bahsedilirken, devletlerin son yıllarda yayılma/süzülme ve seyir füzesi kategorisinde envanterlerine katmaya çalıştıkları silahlar kastedilmektedir. Başta balistik füzeler 
Hipersonik Füzeler ve Stratejik İstikrar:

Rusya-ABD İlişkileri Üzerine Bir İnceleme

olmak üzere son yıllarda farklı silahlar da hipersonik seviyeye ulaşabilse de hipersonik füze kategorisinde mütalaa edilen silahlar süratten ziyade manevra kabiliyetleri ile öne çıkmaktadırlar (Egeli, 2020: 1). Bu nedenle bu çalışmada, hipersonik füzeler kapsamında son dönemde öne çıkan söz konusu füze sistemleri esas odak noktasidır.

$\mathrm{Bu}$ çalışmada, Rusya ve ABD arasındaki askerî-stratejik denge mercek altına alınarak, hipersonik füzelerin bu dengeyi nasıl etkileyebileceği sorusuna yanıt aranacaktır. Rusya-ABD ilişkileri özelinde çalışmanın temel bir hipotezi şu şekildedir:

Hipotez-1: Nükleer silahlar üzerine kurulu stratejik denge üzerinde hipersonik füzeler sinırl bir etkiye sahiptir.

Rusya özelinde bu husus irdelenirken, hâlihazırda kıtalar arası balistik füzeler (ICBM) ve denizaltından gönderilen balistik füzeler (SLBM) ile oluşmuş olan nükleer dengenin stabil olduğu ve hipersonik füzelerin bu dengede kayda değer bir fark yaratmayacağ iddia edilmektedir. Bir diğer hipotez ise şu şekildedir:

Hipotez-2: Hipersonik füzelerin konvansiyonel amaçlı kullanılması, nükleer bir çatışmaya dahi varabilecek istikrarsızlıklar yaratma potansiyeline sahiptir.

$\mathrm{Bu}$ çalışmada vurgulandığı üzere, nasıl olsa nükleer başlık kullanılmadığından hareketle hipersonik füzelerle sergilenebilecek ihtiyatsız eylemlerin, stratejik istikrar üzerinde tahrip edici sonuçlar doğurması muhtemeldir. Sahip oldukları yetkin özelliklerle hipersonik füzeler, konvansiyonelden nükleer aşamaya geçiş riskini artırabilecek unsurlardır. Bu hususları detaylandıracak olan bu çalışma toplam dört bölümden oluşmaktadır. İlk olarak hipersonik silahların, araçların ve füzelerin temel özelliklerine ilişkin bir izahat paylaşılmaktadır. $\mathrm{Bu}$ kısmın ardından, devletlerin hipersonik silah sistemleri geliştirme çabalarına dönük bir arka plan sunulmaktadır. Üçüncü bölümde ise Rusya-ABD ilişkilerinde hipersonik füzelerin etkisi, Rusya merkeze alınarak irdelenmektedir. Bu bölümde, iki büyük güç arasındaki "Dehşet Dengesi'nin" hipersonik füzelerden nasıl etkilenebileceği sorusu masaya yatırlmaktadır. Son olarak ise ABD'nin konvansiyonel vuruş yeteneğini güçlendirmek amacıyla hipersonik silahlara yaptığı yatırıma referansla, Rusya-ABD ilişkilerine temas edilmektedir. 


\section{Hipersonik Füzelere Yakın Plan Bir Bakış}

Hipersonik silahların uluslararası istikrarı ne şekilde etkileyebileceğinin izahı için, öncelikle bu silahlardan ne anlaşılması gerektiğinin net bir şekilde ortaya konulması gerekmektedir. Hipersonik terimi ilk olarak Kaliforniya Teknoloji Enstitüsü'nde görev yapan Hsue-shen Tsien adında bir aerodinamik mühendisi tarafından 1946 senesinde kullanılmış ve bu tarihten itibaren literatüre girmiştir (Lele, 2019: 48). Kelime anlamı itibariyle "hipersonik", herhangi bir objenin sesten beş kat daha hızlı hareket edebildiğini gösteren Mach 5 limitinin aşılması durumunu tanımlamaktadır. Fizikçi Ernst Mach'ın soyadından türetilmiş olan Mach sayısı, bir objenin hızının ses hızına oranlanmasıyla hesaplanır. Söz konusu bir obje ses hızından daha düşük bir hıza sahip olduğunda subsonik, daha yüksek bir hıza sahip olduğunda ise süpersonik kategorisinde değerlendirilir. Fakat söz konusu objenin hızı ses hızının beş katını aşan bir potansiyele sahipse, bu obje hipersonik kategorisinde mütalaa edilir (NASA-Glenn Research Center). Ses hızının 330 metre/saniye olduğu göz önüne alındığında, hipersonik hıza sahip objeler, saniyede 1,65 km'nin ötesinde yol alabilen unsurlardan oluşur (ya da 6.000 $\mathrm{km} / \mathrm{saat})$.

$\mathrm{Bu}$ düzeyde bir hıza ulaşabilen unsurların askerî alanda kullanılmalarının önemli etkiler doğurması kuvvetle muhtemeldir. Öncelikle hipersonik silah sistemleri, saldırıya uğrayan devletler için zaman aralığının çok dar olması ve cevap verme kabiliyetinin ciddi ölçüde azalması nedeniyle önemlidir. Bu bağlamda hız, tek değişken olmasa da, hipersonik silahların temel özelliğidir. Aşağıda da değinileceği üzere, uzun bir süredir devletlerin envanterinde yer alan balistik füzeler de hipersonik hız limitine ulaşabilen unsurlardır. Fakat manevra ve alçak irtifadan uçabilme gibi yeni yetenekleri bünyesine katan hipersonik füzeler, işlevsellik anlamında füze sistemlerine ayrı bir boyut kazandırmışlardır. Hipersonik füzeler hem konvansiyonel hem de nükleer başlık taşıyabilmekte olup, literatürde bu unsurlardan bahsedilirken, iki adet silah sistemine atıf yapılmaktadır. Bunlar, Hipersonik Seyir Füzesi (HCM) ve Hipersonik Yayılma (ya da Süzülme) Aracı'dır (HGV).

HCM'ler hâlihazırdaki seyir füzelerinin daha süratli bir şekilde yol alabilen versiyonu olup, bu unsurlar üst düzey hız limitine scramjet motor sistemi sayesinde ulaşmaktadır. Daha geleneksel bir model olan ramjet, bünyesinde sıv1 oksijen barındırmakta ve bu maddenin hidrojenle birleşmesi sonucu istenen enerjiyi elde 
Hipersonik Füzeler ve Stratejik İstikrar:

Rusya-ABD İlişkileri Üzerine Bir İnceleme

etmektedir. Fakat bu işleme dâhil edilen oksijen, aracın ağırlığını arttırmakta ve böylece hızını ve menzilini azaltmaktadır. Scramjet sayesinde ise hipersonik araçlar, uçuş hâlinde seyrederken oksijeni dışarıdaki atmosferden içine almakta ve daha sonra bünyesindeki hidrojen yakıtıyla oksijenin birleşmesi sonucu oluşan yanma gücüyle birlikte hipersonik bir hız seviyesine erişmektedir (Missile Defense Advocacy). HCM'ler deniz saldırıları, hava ya da deniz platformlarından kara saldırıları ve komşu ülkeler arasında sınır ötesi ani saldırılar gerçekleştirilmesi düşünülen anlarda işlev görebilecek silahlardır (Gubrud, 2015: 3). HCM'ler seyir füzelerine önemli bir niteliksel katkı sağlamışsa da hipersonik füze sistemlerine yönelik ilginin yoğunlaştığı asıl unsur HGV'lerdir (The Economist, 2019: 67). Zira kıtalar arası balistik füzelerin yerini almaya aday gösterilen bu unsurlar, özellikle büyük güçler arasındaki stratejik denklemi etkileme kapasiteleriyle ayırt edici bir özellik taşımaktadır.

HCM'lerden farkl1 olarak HGV'ler ilave enerji talep etmeden, yayılma/süzülme hareketleriyle belirli bir hedefe ulaşabilme yeteneğine sahiptir. HGV olarak bilinen füzelerin gönderilmesi balistik füzelere benzer şekilde gerçekleşse de, bu silahları yekdiğerinden ayrıştıran önemli bir teknik özellik mevcuttur; balistik füzeler atmosferin üzerine çıkarak bir yay şeklinde seyahat ettikten sonra hedefe ulaşırken, HGV'ler firlatma işlemi sırasında kullanılan roketten ayrıldıktan sonra kısa bir süre parabolik bir seyir izlemekte, daha sonra ise atmosfere çok hızlı bir şekilde giriş yaparak yayılma/süzülme hareketleriyle hedefe kilitlenmektedir (Acton, 2018; Gubrud, 2015: 2). Aşağıda Şekil-1'de, mavi renkteki balistik füzenin ve kırmızı renkteki HGV'nin nasıl farklı seyirler izledikleri görülmektedir. 


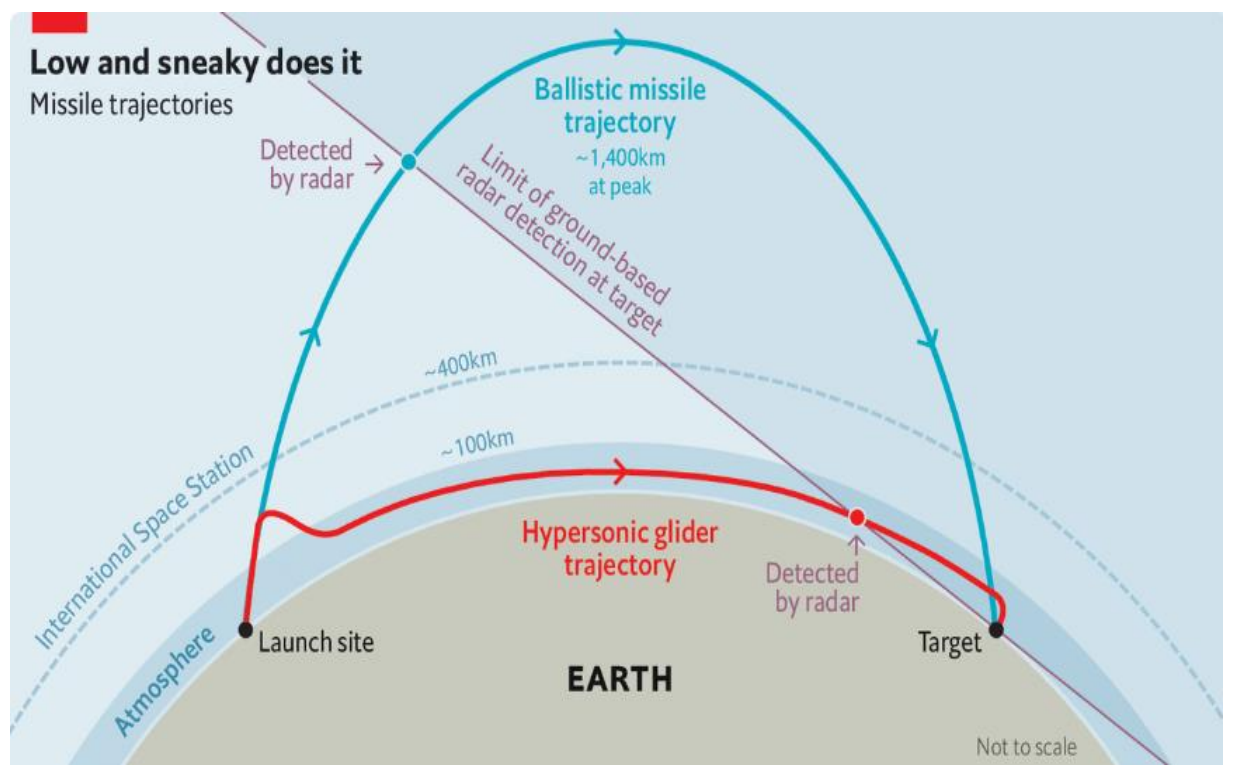

Şekil 1. Balistik Füzeler ve HGV Araçlarının Uçuş Seyirleri (The Economist, 2019: 68)

Balistik füzelere kıyasla daha düşük irtifadan uçabilen $\mathrm{HGV}^{\prime}$ ler, balistik füzelerin takibini yapan radarların kapsamına daha geç girmektedir (Gubrud, 2015: 2). Balistik füzelerin, HGV kategorisindeki silahlarla kıyaslanabilecekleri temel husus ise hızlarıdır. Zira balistik füzeler de hipersonik düzeye ulaşabilme yeteneğine sahiptir. Fakat balistik füzelere karşı devletlerin hava savunma sistemleri füzeleri tespit ve imha edecek şekilde takviye edildiklerinde belli bir koruma kalkanı işlevi görebilirken, HGV'lere karşı bu işlev çok daha zordur. Zira HGV'ler etkili manevra yetenekleriyle mevcut füze savunma sistemlerini etkisiz bırakabilecek unsurlardır. Her ne kadar balistik füzelerin taşıdığı savaş başlıkları "siçrama manevrası ve terminal fazda hareket kabiliyeti ile az çok manevra yapabilir hale gelse de bu kabiliyet sınırlıdır" (Kılıç, 2018). Manevra yetenekleri ile hipersonik füzeler, seyir hâlindeyken bir hedeften farklı bir hedefe yönelebilme imkânına sahiptir. $\mathrm{Bu}$ çerçevede, balistik olmayan hipersonik silah sistemlerinin varacağı hedefin, karmaşık uçuş seyri nedeniyle, son ana kadar bilinmesi mümkün olmayabilir (Wilkening, 2019: 131). Öngörülebilirlik faktörünün zedelenmesi sonucunda devletlerin, ani bir hipersonik saldırıda askerî güçlerini topyekûn kaybetme tehdidini hissetmeleri dahi muhtemeldir (Speier vd., 2017: xiii, 8-9). Manevra yeteneği bakımından HGV'ler ile kıyaslanabilecek asıl unsurlar subsonik 
Hipersonik Füzeler ve Stratejik İstikrar:

Rusya-ABD İlişkileri Üzerine Bir İnceleme

seyir füzeleridir. Fakat bu füzeler, etkili manevra kabiliyetlerine rağmen, düşük bir hız kapasitesine sahiptir. Balistik füzeler ise hız olarak hipersonik seviyeye ulaşsalar da manevra kabiliyetleri zayıftır (Speier vd., 2017: 7). Böylece manevra yeteneği; hız ve kesinlik gibi etkenlerle birleşince, hipersonik füzelerin ayırt edici niteliği ortaya çıkmaktadır (Egeli, 2020: 1; Mackinnon, 2019; Kılıç, 2018).

Hipersonik füzeler, ICBM ya da SLBM unsurları ile sevk edilebilmektedir. Bununla birlikte, seyir füzesine benzer şekilde, bombardıman uçağı tarafindan da sevk edilmeleri mümkündür. Hipersonik füzelerin etkin silah sistemleri olarak mütalaa edilmesinde, hız kapasitelerine rağmen içerdiği unsurların zarar görmemesi belirleyicidir. Zira hipersonik hızda oluşan sürtünme ve sarsıntı o kadar güçlüdür ki, araç bu çevresel yüklerden olumsuz etkilenebilmektedir. Uzmanların aktardığı bilgilere göre, hipersonik bir aracın yapısı kalkışta ve inişte farklı bir nitelik kazanmakta olup, aracın dış yüzeyinde ve yapısal unsurlarında ciddi değişimler meydana gelebilmektedir. Bu bağlamda, hipersonik hıza geçildiğinde oluşan basınç ve isı nedeniyle hipersonik araçlar henüz hedeflerine ulaşamadan zarar görmekte, hatta parçalanabilmektedir (Leyva, 2017). Hâlihazırda yapılan çalışmalarda özellikle yüksek ısının neden olabileceği sorunların aşılmasına özel bir önem verilmektedir. Hipersonik aracın hızı arttıkça, 1sı seviyesi geometrik bir artış göstermektedir. Örneğin Mach $4^{\prime}$ te $650^{\circ} \mathrm{C}$ 'lik bir 1sıya ulaşan yüzey tabakası, aracın hızı Mach 6'ya ulaştı̆̆ında iki misli $\left(1300^{\circ} \mathrm{C}\right)$, Mach 8 'e ulaştı̆̆ında ise dört misli $\left(2600^{\circ} \mathrm{C}\right)$ bir 1s1 seviyesine ulaşmaktadır (The Military Balance, 2013: 27). Hipersonik hizda sürtünme ve hava direnci nedeniyle oluşabilecek sorunlara cevaben "yüksek 1sıya dayanıklı gelişmiş/akıllı malzemeler, minyatürleştirilmiş takat, kontrol ve seyrüsefer sistemleri, gelişmiş uçuş dinamiği modelleme ve simülasyon imkânları" gibi olanaklar kullanılmaktadır (Egeli, 2020: 2). Bir bütünlük içinde ele alındığında, hız limiti üst seviyelere tırmanmasına rağmen gerek güdümlü sistemlerin gerekse mühimmatın oluşan 1sınmadan kaynaklı olarak zarar görmemesi, hipersonik araçların başarısının anahtarıdır. Hâlihazırda test edilen hipersonik füzelerin, devletlerin tam teşekküllü olarak kullanımına girmeleri durumunda "malzeme biliminde" önemli bir aşamanın kat edilmiş olduğu gerçeği kanıtlanmış olacaktır (Kofman, 2019). 


\section{Hipersonik Silahlara İlerlenen Süreç}

Her ne kadar hipersonik füzeler son yıllarda artan bir ilgi görmüşse de bu silahları devletlerin envanterine katmaları yaklaşık bir asırlık bir geçmişe dayanmaktadır. Hipersonik füzelerin gelişim sürecine bakıldığında, 1928 yılında Almanya'da roketle güçlendirilmiş planör füzesinin denemesinin yapılması bu süreçte önemli bir milat teşkil etmiştir (The Economist, 2019: 68). 1930'lu yıllara gelinmesiyle birlikte roket teknolojisine dönük araştırmalarını yoğunlaştıran Almanya, 1941 senesine gelindiğinde ise Aggregat füze serisinin ilki olan Vergeltungswaffe-1 (V-1) adlı modeli kullanıma sokmuştur. Almanya'nın İkinci Dünya Savaşı zamanına denk gelen füze sistemlerine yatırım yapma süreci, Nazilere savaşın son yıllarında artık uçaklarla elde edemedikleri stratejik saldırıları, sınırlı düzeyde de olsa, gerçekleştirme imkânını tanımıştır. Savaş sırasında, Alman mühendis Wernher Von Braun'ün çabaları sonucu Vergeltungswaffe-2 (V-2) roketinin seri üretimine geçilmiş ve bu sayede Almanya, bir ada ülkesi olan hasmı Britanya'yı Kıta Avrupa'sından kısa sürede hedef alabilmiştir. Bir ton patlayıcı ihtiva eden 14 metre uzunluğunda bir roketi Britanya'ya yalnızca altı dakikadan az bir sürede ulaştırabilen Almanya, Londra ve Kent gibi şehirlere büyük hasarlar vererek, binlerce insanın hayatına mâl olacak saldırılar gerçekleştirmiştir. V-2'nin tahribat kapasitesinde içerdiği patlayıcı mühimmat önemli bir etken olmuşsa da bu silahı asıl öne çıkaran unsur hız kapasitesi olmuştur. Nitekim saniyede 800 metre mesafe kat eden ve birçok ateşli silahta kullanılan kurşundan dahi hızlı seyreden V2'nin takip ve tespiti imkân dışında kalmıştır (Bergaust, 2017: 81-82). Saatte 5.400 $\mathrm{km}$ yol alabilme kapasitesiyle V-2, hipersonik seviyeyi neredeyse yakalama noktasına gelmiştir (Oelrich, 2020: 38).

Almanya'nın roket teknolojisinde kaydettiği ilerleme, İkinci Dünya Savaşı'nın galip devletlerinin gözünden kaçmamış ve özellikle ABD, Alman mühendislere kucak açan bir politika izlemiştir (Konuyla ilgili bkz; Bergaust, 2017: 87-97; Spangenburg ve Moser, 2008). İkinci Dünya Savaş1 sonras1 süreçte $\mathrm{ABD}$, savaşın kazanan tarafında yer almasına rağmen özellikle hava unsurlarını daha da güçlendirme ihtiyacı hissetmiştir. Bu hususla ilgili iki faktör belirleyici olmuştur. İlki, o yıllarda sadece ABD'nin sahip olduğu atom bombasının gerekli hedeflere ulaştırılması için yetkin bir hava gücüne ihtiyaç duyulması; ikincisi ise, önceden Nazi Almanya'sı, Soğuk Savaş'ın başlamasıyla ise SSCB'nin ABD ana karasını hedef alabilecek hava unsurları geliştirme çabalarının görülmesi olmuştur. 
Hipersonik Füzeler ve Stratejik İstikrar:

Rusya-ABD İlişkileri Üzerine Bir İnceleme

Bunun karşısında $\mathrm{ABD}$, insanlı ya da insansız, gerekli hava araçlarına sahip olmaya ve böylece askerî rekabette potansiyel rakiplerinin önünde yer almaya çalışmıştır. Hangi silah sistemlerinin geliştirilmesi konusunda müzakereler devam ederken, bir grup bilim adamı, insan beyninin hiçbir mekanik araçla ikame edilemeyeceğini belirterek, pilotlu araçların üretimini müdafaa etmiş; bir diğer grup ise SSCB'nin balistik füze programına yaptığı yatırımın gerisinde kalmamak için insansız hava unsurlarına ağırlık verilmesini önermiştir (Houchin II, 2006: Chapter-1). İkinci Dünya Savaşı'nda elde edilen başarının etkisiyle Amerikan Hava Kuvvetleri'nde ağırlıklı görüş, insanlı hava aracına odaklanılması olmuştur (Builder, 2017: 31-32). Fakat ilerleyen yıllarda bu görüş revize edilmiştir. Hava Kuvvetleri Kurmay Başkanı Thomas D. White'ın "süvarilerin atlarına bağlı olduğu gibi, havacılar da uçaklarına bağlı" olduğu görüşünde ifade bulduğu üzere, statüko politikasının bir yana bırakılması ve yeni koşullara adapte olunması gerektiği görülmüştür (Werrell, 1985: 103).

Soğuk Savaş koşullarının belirginleşmesiyle birlikte ABD her iki alanda da çalışmalar yürütürken, hız limitinin üst noktalarına ilk olarak insanlı hava aracı ile ulaşmıştır. 1950'lerden itibaren üzerinde çalışılan X-15 model insanlı hava aracı ile hipersonik limitin ötesine geçilmesinde ilk başarı sağlanmıştır. Uçuş için atmosferin ötesindeki koşulları ve bunun hava araçları üzerindeki etkisini test etmek için geliştirilen X-15 uçağı, 1967 senesinde Mach 6,7'lik bir sürate ulaşarak, bir hız rekoruna imza atmıştır. Öte yandan, ses hızını aşan kıtalar arası seyir füzelerinin geliştirilmesi yönünde çalışmalar da yapılarak, askerî rekabette ABD'ye avantaj kazandıracak yeni yeteneklere ulaşılmaya çalışılııştır. Bu bağlamda takat, güdüm ve firlatma sistemleri alanlarında çalışmalar yürütülerek ABD'nin roket teknolojisinde ilerlemesine çaba gösterilmiştir (Banham, 2015: 98).

Aşağıda ele alındığı gibi, SSCB'nin ICBM özelinde kat ettiği ilerleme ABD’yi bu alandaki açığı kapatmaya sevk etmiştir. Devlet Başkanı Dwight Eisenhower'ın devreye girmesiyle bombardıman uçaklarına ağırlık verilmesini savunan Hava Kuvvetleri'nin direnci kırılmıştır. Bunun sonucunda 1959 senesinde ICBM programına odaklanılması ve uzay yarışında rekabet gücünün artırılması için Vanguard uydusunun firlatılması, savunma alanındaki öncelikler olarak belirlenmiştir (Builder, 2017: 138). 1959 sonrası dönemde ABD; Atlas, Titan, Minuteman ve MX olarak bilenen dört temel ICBM'ye sahip olmuştur (Norris ve Kristensen, 2009: 64). ICBM alanında Minuteman III özelinde görüldüğü gibi, 
software, MIRV teknolojisi ve güdüm sistemi alanlarında kaydettiği ilerlemeyle ABD (The Military Balance, 1978: 3) SSCB ile arasındaki nitelik makasını açmaya çalışmıştır. 23 Mach'lık bir hıza sahip olan Minuteman III gibi ICBM'ler ile hipersonik süratin alt limiti olan 5 Mach'ın yaklaşık 5 kat üzerine çıkılmıştır (Air Force Global Strike Command, 2017). Bu füzeler ilk anda tek savaş başlığına sahip olmuşlarsa da 1970’ten itibaren Bağımsız Hedeflenebilir Yeniden Giriş Aracı (MIRV) ile donatılmaya başlamışlardır. Bu sayede ICBM'lere monte edilen savaş başlığı sayısı beş yıldan az bir sürede iki katına çıkmıştır (Norris ve Kristensen, 2009: 64). MIRV özelinde yaşanan gelişme, Manevra Yapabilen Yeniden Giriş Aracı (MARV) özelinde de yaşanmıştır. ABD, 1960'lardan itibaren bu araçların geliştirilmesi konusunda uyguladığı testlerle SSCB'nin önünde yer almıştır (Leggett, 1975: 99; Caston vd., 2014: 69). MARV teknolojisine yapılan yatırımla yüksek isabetlilik, füze savunma sistemlerinin aşılabilmesi ve hareketli hedeflerin vurulabilmesi gibi alanlarda mesafe kat edilmiştir (Caston vd., 2014: 67-69). Savaş başlıklarının etkinliği ve özellikle manevra yeteneği, hipersonik füzelerin performansında da direkt belirleyici olduğu için, ABD'nin kat ettiği ilerlemeler, SSCB'nin bir adım ötesinde olmasına imkân tanımıştır.

Soğuk Savaş'ın diğer cephesinde bulunan SSCB de gerekli hava gücüne sahip olmak için kararlı adımlar atmıştır. Savaş sonrası SSCB safina katılan Alman mühendislerin katkılarıyla V-2 füzesinin benzerinin üretimine başlanmış, 1948 yılında ise V-2 roketinin gelişmiş modeli olan R-1'in (SS-1 Scud) üretimi tamamlanmıştır. $\mathrm{Bu}$ sürecin devamında daha da fazla menzile sahip füzelerin üretimine odaklanılmış ve 1949 'da R-2 model balistik füzenin testleri başarı ile tamamlanmıştır (Harrison, 2000; Afanasyev, 1998). Bu süreç, ICBM ve SLBM üretimi ile takip edilmiştir. ABD'den beş ay önce SSCB, Ağustos 1957'de, ilk ICBM denemesi gerçekleştirmiş, 4 Ekim 1958'de ise, ABD'nin kaygılarını arttıran bir gelişme olarak, ilk yapay uydu Sputnik'i uzaya göndermiştir (Judt, 2005: 248). Kaydedilen bu başarı ile SSCB topraklarından gönderilen bir füzeyle ABD ana karasının vurulabileceğini gösterilmiştir (Shoumikhin, 2011: 102). Denizden gönderilecek balistik füzelerle ilgili olaraksa, R-11'in (Scud-A) modifiye edilmiş versiyonu olan R-11M, 1959 y1lında Sovyet deniz gücüne katılmıştır. 150 ila 167 $\mathrm{km}$ arasında menzile sahip olan R-11M, üretilen ilk SLBM olarak kayda geçmiştir (Federation of American Scientists, 2000).

ABD gibi SSCB de, ürettiği balistik füzelerle hipersonik seviyenin üzerine çıkan araçlara sahip olmuştur. Örneğin ICBM kategorisinde SS-18 Satan, yaklaşık 
Hipersonik Füzeler ve Stratejik İstikrar:

Rusya-ABD İlişkileri Üzerine Bir İnceleme

olarak 28,5 Mach'lık bir hıza erişmiştir (Army Technology, 2013). Füze sistemlerine verdiği önem çerçevesinde SSCB, Soğuk Savaş'ın müteakip yıllarında geride olduğu alanlarda ABD'yi yakalayarak rakibi ile parite noktasında olmaya çalışmıştır. ABD, MIRV ile donatılan ICBM ve SLBM'leri 1970'den itibaren kullanmaya başlamışken, SSCB için bu süreç 1975 yılında başlamıştır (Leitenberg, 1984: 1). İlerleyen yıllarda SSCB daha fazla sayıda MIRV taşıyabilen ve isabetlilik konusunda daha yetkin füzeler üreterek, rakibi ile arasındaki makası kapatmaya çalışmıştır (Norris ve Kristensen, 2009: 68; Walsh, 2008: 32-34; The Military Balance, 1978: 3-4). MARV alanında da benzer bir durum yaşanmıştır. Ronald Reagan döneminde ABD’nin Stratejik Savunma Girişimi konsepti çerçevesinde silah yarışını bir aşama yukarı taşımasına cevap olarak SSCB, MARV teknolojisini geliştirme ve böylece nükleer silahlarla ABD'nin savunma kalkanını delme amaçlı çalışmalarını yoğunlaştırılmıştır (Acton, 2013: 106).

SSCB'nin 1970'lerden başlamak üzere MIRV ve MARV teknolojilerine yaptığı yatırım, hipersonik araçların geliştirilmesi sürecine katkı sunacak bir mahiyet taşımıştır. SSCB'nin hipersonik silahların geliştirilmesine ağırlık verme süreci esas olarak 1980'lerin ortasında Albatross adlı bir projenin hayata geçirilmesiyle başlamıştır (Lele, 2019: 60). Albatross, bir sonraki kısımda ele alınacak olan Avangard projesinin bir ön aşamasını teşkil etmiş ve Rusya'nın HGV kategorisinde hipersonik araçlar geliştirmesinde önemli bir milat olmuştur. Ayrıca bu süreçte SSCB, hipersonik hıza ulaşan uçak, modifiye edilmiş S-200V hava savunma sistemleri ve Kh-80 ve Kh-90 GELA gibi hipersonik seyir füzesi programları ile ses hızının ötesine geçen unsurlar geliştirmeye çalışmıştır (Kofman, 2019). SSCB'nin bu yöndeki çabaları özellikle Soğuk Savaş’ın sonlanma sürecine denk gelmiş ve Sovyet dönemi bitmek üzereyken, Raduga tasarım bürosunda Kh90 seyir füzelerinin geliştirilmesine başlanmıştır. Bununla birlikte, TU-95 uçaklarında yeni uçuş donanımları test edilerek, hız kapasitesinin üst limitlerine ulaşılmaya çalışılmıştır (The Military Balance, 2013: 27).

SSCB'nin hipersonik araçlara yapmaya başladığı yatırımlar ABD tarafindan da yakından takip edilmiştir. ABD'li uzamanlar, SSCB'nin askerî doktrininde "sürpriz" faktörüne vurgu yaparak, olası bir savaş senaryosuna karşı SSCB'nin askerî havacılık ve gözetleme gibi alanlarda kullanılacak ve ayrıca uydu sistemlerine saldırı gerçekleştirebilecek hipersonik silah sistemleri geliştirmeye çalıştığını aktartmışlardır. SSCB'nin Hava Kuvvetleri Komutanı Aleksandr 
Yefimov'a atıfta bulunularak, hipersonik özelliğe sahip uçakların önleme uçağı ve gözetleme uçağı olarak kritik görevler ifa edecekleri öngörülmüştür. Her ne kadar 1980'lerin sonlarında yaşanan bu gelişmeler SSCB'nin son lideri Mikhail Gorbaçov'un ABD ile ilişkileri normalleştirmeye çalıştığı zaman diliminde yaşanmışsa da SSCB'nin hipersonik araçlara yapmaya başladığı yatırım, önceki dönemde yaşanan rekabetin 1şığında, ABD tarafından yakinen takip edilmiştir (Paragraftaki detaylar için bkz; Johnson, 1988).

\section{Hipersonik Füzeler ve "Dehșet Dengesi"}

Soğuk Savaş'ın iki cephesinden birine liderlik eden SSCB'nin 1991 senesinde dağılması, on dört diğer Sovyet cumhuriyeti ile birlikte Rusya Federasyonu'nun yeni ve bağımsız bir devlet olarak uluslararası siyaset sahnesine çıkmasına neden olmuştur. 8 Aralık 1991 tarihli Belavezha Anlaşması ile SSCB resmi olarak ortadan kalktıktan sonra, bu ülkenin hukuki anlamda "devamı" niteliğindeki ülke Rusya Federasyonu olmuştur. Rusya, SSCB’nin imzaladığ 1 uluslararası antlaşmaları devralarak, uluslararası hukuk bağlamında yasal bir mükellefiyete sahip olmuştur (Sakwa, 2008: 368). Bunun uluslararası istikrar açısından önemli bir sonucu söz konusudur: ABD-SSCB arasında stratejik istikrarı sağlamayı amaçlayan köşe taşı niteliğindeki askerî antlaşmaların Soğuk Savaş sonrasındaki taraflarından biri SSCB yerine Rusya olmuştur. Soğuk Savaş sırasında SSCB ve ABD arasında SALT-1, SALT-2, START-1, INF ve Anti-Balistik Füze (ABM) Antlaşması gibi bir dizi kritik antlaşma imzalanarak, ilişkilerde stratejik istikrarın mümkün kılınması konusunda ortak bir irade benimsenmiştir. Bu yöndeki irade, stratejik silah sistemlerinden kaynaklanan tehlikeleri azaltarak, dünyayı nükleer bir savaştan uzak tutma düşüncesine dayanmıştır.

Benzer bir düşünce Soğuk Savaş sonrası dönemde de iki ülkenin liderleri tarafindan benimsenmiştir. George H. W. Bush ve Boris Yeltsin arasında 1993'te imzalanan START-2 ve Dimitri Medvedev ve Barack Obama arasında 2010'da imzalanan "Yeni START" (New START) antlaşmalarıyla, nükleer silahlardan

kaynaklanan tehlikenin azaltılması iradesi Soğuk Savaş sonrasında da sürdürülmüştür. Fakat bu olumlu süreç, 2001 y1lından itibaren önemli engellerle de karşılaşmıştır. ABD’nin 1972 tarihli ABM Antlaşması'ndan 2001 yılında tek taraflı olarak geri çekilmesi, olumsuz gelişmeler bakımından ilk işaret fişeği olmuştur. 2019 yılında ise Donald Trump yönetimi, Orta Menzilli Nükleer Kuvvetler 
Hipersonik Füzeler ve Stratejik İstikrar:

Rusya-ABD İlişkileri Üzerine Bir İnceleme

Antlaşması (INF) olarak bilinen ve 500 ila $5.500 \mathrm{~km}$ arasında menzile sahip yerden ateşlenen balistik ve seyir füzelerinin kullanımını yasaklayan antlaşmadan ABD'nin çekildiğini deklare etmiştir. ABD'nin 2021'de sonlanacak olan Yeni START Antlaşması'yla ilgili olarak nasıl bir tavır benimseyeceği ise önemli bir soru olarak ortada durmaktadır. Bu antlaşmanın da öncülleri gibi sonlanması durumunda, iki büyük güç arasında stratejik silah sistemlerinin kontrolünü amaçlayan bütün antlaşmalar geçerliliğini yitirmiş olacaktır. ${ }^{1}$

ABD'nin Soğuk Savaş sürecinin bir ürünü olan kritik antlaşmalardan çekilmesi Rusya tarafından tepkiyle karşılanmıştır. Rusya'nın rahatsızlıklarının yoğunlaştı̆̆ esas husus ise ABM Antlaşması'nın sonlanması olmuştur. ABM Antlaşması, Soğuk Savaş sırasında iki süper güç arasındaki ilişkiyi Dehşet Dengesi (Mutually Assured Destruction) prensibi üzerinden sabitlemeyi amaçlayan bir inisiyatif olarak 1972'de yürürlüğe girmiştir. Dehşet Dengesi çerçevesinde, nükleer silah kullanmanın kendi yok oluşuna neden olacağını bilen iki ülke, stratejik dengeyi tahrip etmekten kaçınmıştır. ABM'nin temel işlevi ise uluslararası bir antlaşma marifetiyle bu dengeyi yasal bir düzleme oturtmak olmuştur. Muhtevası itibariyle ABM Antlaşması, SSCB ve ABD'ye sadece iki lokasyona füze savunma sistemleri konuşlandırma hakkı tanımıştır. Bu lokasyonlardan biri başkenti diğeri ise herhangi bir ICBM firlatma alanını koruma amaçlıdır. Füze savunma sistemlerinin konuşlandırıldığı alanlarda her iki ülke de azami olarak 100'er firlatma sistemi ve 100 'er önleme füzesi bulundurabilmektedir. 1974 tarihli bir protokol ile lokasyon sayısı ikiden bire indirilmiştir. Ayrıca antlaşma, tüm erken uyarı radarlarının imzacı ülkenin sınır boyundaki bölgelere yerleştirilmesini şart koşmuştur. İmzalanan bu antlaşma gereğince, her iki ülke de rakibinin olası bir saldırısında ülkesinin yalnızca sınırlı bir bölgesini koruyabileceğini kabul ederek, balistik füzelerin sağladığı caydırıcılık üzerine kurulacak stratejik dengenin tesis edilmesine onay vermiştir. Böylece ICBM ve SLBM'leri etkisiz hale getirebilecek füze savunma sistemleri konuşlandırılmayarak, Dehşet Dengesi'nin devamı sağlanmaya çalışılmıştır. Nihai kertede, her iki taraf da herhangi bir misilleme ile karşılaşmadan rakibinin nükleer silah envanterini yok edemeyeceğini bildiğinden, nükleer çatışmasızlığın sağlanabileceği öngörülmüştür (Freedman, 2013).

\footnotetext{
${ }^{1}$ Makalenin yayınlanmasına kısa bir süre kala, ABD'de yeni seçilen Joe Biden hükümeti ile Rusya hükümeti anlaşmış ve Yeni START Antlaşması beş seneliğine uzatılmıştır.
} 
Rusya'nın ABM Antlaşması'nın işlevsiz hale gelmesine dönük itirazları, Soğuk Savaş zamanında tesis edilen stratejik istikrarın bozulması iddiası üzerinden seslendirilmiştir. 2000 yılında Rusya devlet başkanlığına seçilen Vladimir Putin, görevinin ilk yıllarından itibaren ABM Antlaşması'nın önemine dikkat çekerek, bu inisiyatifin geçerliliğini yitirmesinin olumuz tarafına vurgu yapmıştır. Putin, ABM Antlaşması'nın uluslararası güvenlik açısından "köşe taşı" mahiyetinde bir inisiyatif olduğunu vurgulayıp, ABD'nin Polonya ve Romanya'da oluşturmakta olduğu füze savunma sistemleri nedeniyle Rusya'nın stratejik nükleer silahlarının artık tehdit altında olduğunu aktarmıştır. Rusya liderine göre ABD'nin ABM Antlaşması'ndan çekilme kararının sonucu, stratejik dengenin bozulmasıdır ve bu durum uluslararası güvenliğe dönük ciddi bir tehdittir (Kremlin, 2017).

Obama döneminde ABD Savunma Bakan Yardımcısı olarak görev alan Nükleer Strateji Uzmanı Brad Roberts'ın belirttiği gibi, Rusya ve Çin gibi güçlü rakipler, ABD’nin "mutlak güvenlik” elde etmek istediğini düşünmektedir. Bu düşüncenin ana ekseni, ABD'nin istediği aktöre istediği zaman saldırma yeteneğine sahip olmayı istemesi, ama misillemeden de muaf kalmaya çalışmasıdır. Roberts, ABD'nin böyle bir düşünceye sahip olduğunu reddetmekle beraber, mutlak güvenlik arayışında bulunulmasının tehlikeli bir gelişme olacağını kabul etmektedir (Sato, 2020). Bunun nedeni, rakip güçlerin önüne kurulan hava ve füze savunma sistemlerinin, bir saldırı durumunda bu aktörlerin ikinci vuruş kapasitelerini etkisiz hale getirebilecek olmasıdır. Nitekim ABD karar alıcıları farklı bir kanaate sahip olsalar da, Rusya tarafındaki hissiyat, ABD'nin rakip aktörlerinin güvenlik ihtiyacını göz ardı ederek, kendi güvenliğini arttırmaya çalıştığı şeklinde olmuştur (Corriere Della Sera, 2015).

ABM Antlaşması özelinde Rusya, Batı'nın dışlama politikasına bir cevap olarak çeşitli adımlar atmış ve bu adımların başında hipersonik füze sistemleri geliştirmek gelmiştir. Böylece, ABD menşeli hava ve füze savunma sistemlerinin Rusya tarafından aşılabileceği kanıtlanmaya çalışılmıştır. Putin'in vurguladığı gibi, füze savunma şemsiyesi oluşturarak stratejik dengeyi bozanlar yanlış bir hesapla Rusya'nın bunu aşamayacağını düşünmüşlerdir. Fakat Rusya, balistik füzelere karşı geliştirilen füzesavarları ekarte edebilecek ve kıtalar arası özelliğe sahip taarruzi hipersonik silahlar geliştirmiştir. Putin aynı görüşünde, güç dengesi sayesinde İkinci Dünya Savaşı'ndan beri büyük savaşların engellenebildiğine dikkat çekerek, geliştirdiği hipersonik silahlarla Rusya'nın stratejik dengenin korunmasına yardımcı olduğunu aktarmıştır (TASS, 2020). Bu hususlar 
Hipersonik Füzeler ve Stratejik İstikrar:

Rusya-ABD İlişkileri Üzerine Bir İnceleme

vurgulanarak, Rusya'nın nükleer caydırıcılığını zayıflatmayı amaçlayan girişimlerin sonuçsuz kaldığı belirtilmiştir.

Yakın döneme ait bir okuma yapıldığında, ABM Antlaşması'nın sonlanması ve Putin'in başkanlığa gelmesinin ilk yıllarından itibaren Rusya'nın hipersonik silah sistemleri geliştirme çabalarına ağırlık verdiği görülecektir. Rusya, 1990'da iki farklı test uçuşu gerçekleştirdiği YU-70 model HGV'nin, 2001 ve 2004 senelerinde yeni testlerini gerçekleştirmiştir (United Nations Office for Disarmament Affairs, 2019: 10). İlerleyen zamanla birlikte Rusya, hipersonik silah sistemleri geliştirme çabalarını yoğunlaştırmıştır. Bu bağlamda, ABD’nin Soğuk Savaş döneminden itibaren hipersonik silahlara yapmış olduğu yatırıma denk bir mesafe kat edilmeye çalışılmıştır. 2012 senesinde Rusya Başbakan Yardımcısı Dimitri Rogozin, ABD'nin hipersonik araçlar üretme konusundaki üstünlügüne referansla, bu ülkenin muadili bir rakibin ortaya çıkması gerektiğini belirtmiştir. Rekabette geri kalmamak için Rusya hükümeti tarafından gerekli adımlar atılırken, roket sistemleri üretiminde önemli bir bilgi birikimine sahip olan NPO Mashinostroyenia, Taktik Füze Şirketi adlı bir diğer kuruluşun bünyesine katılmıştır. Taktik Füze Şirketi, Raduga gibi güdümlü silah sistemleri üreten firmaları bünyesinde barındıran bir inisiyatif olarak NPO Mashinostroyenia'yı da içine katarak, bir güç birliği oluşturmaya çalışmıştır (The Military Balance, 2013: 26-27).

$\mathrm{Bu}$ adımların atılmasını takip eden dönemde Rusya, hem HCM hem de HGV araçları geliştirme konusunda olumlu sonuçlar almıştır. Örneğin, 1.000 km'ye kadar menzile ve yüzlerce kilometre derinlikteki hedefleri imha edebilme kapasitesine sahip olan Zircon 3M-22 hipersonik seyir füzesinin deneme uçuşlarında sağlanan başarılar, HCM kategorisinde Rusya'nın gerçekleştirdiği ilerlemeyi gözler önüne sermiştir. 8 Mach düzeyinde bir hıza ulaşabilen Zircon'un, ilk aşamalarda konvansiyonel başlık taşıyan gemisavar füze olarak kullanılması düşünülmüșse de, Rus karar alıcılar, Zircon'un Tomahawk füzesine benzer șekilde hem nükleer hem de konvansiyonel başlık taşımasını tasarlamaktadır. Rus Amiral Vsevolod Khmyrov'un verdiği bilgiye göre, Rus deniz gücü her bir denizaltıdan 40 adet Zircon'u aynı anda ateşleyerek ABD askerî unsurlarını hedef alabilme kapasitesine sahiptir (Global Security). ${ }^{2}$

${ }^{2} \mathrm{Bu}$ tartışma kapsamında Rusya'nın nükleer güçle çalışan hipersonik seyir füzesi geliştirme yönünde adımlar atmakta olduğu da vurgulanmalıdır. Bu yönde önemli 
Rusya'nın hâlihazırda envanterinde bulunan bir diğer hipersonik füze sistemi ise Kinzhal'dır. Hem konvansiyonel hem de nükleer başlık taşıma yeteneğine sahip olan Kinzhal, havadan firlatılan ve 10 Mach'lık hıza ulaşabilen bir balistik füzedir. $\mathrm{Bu}$ sistemin üretilmesinin arkasındaki kuvvetle muhtemel neden, Avrupa'daki NATO unsurlarının kullanımında olan havaalanları, silah depoları ve komuta merkezleri gibi stratejik hedefleri imha edebilmektir. Kinzhal, 1.500-2.000 km menzille görece düşük bir yol alabilme kapasitesine sahip olsa da manevra yeteneği ile ABD'nin Terminal Yüksek İrtifa Bölgesel Savunma Sistemi (THAAD) ve Patriot PAC-3 füze savunma sistemlerini zorlayabilecek bir hipersonik füzedir (Missile Defense Project, 2018a). Öte yandan bazı analizlerde, uygulanan testlerde Kinzhal'ın menzilinin sadece $805 \mathrm{~km}$ olarak tespit edildiği hatırlatılarak, Rusya tarafından yapılan açıklamaların doğru bir resim sunmadığı aktarılmaktadır (Majumdar, 2018). Bu durumda, ABD'nin füze savunma unsurları Kinzhal karşısında daha etkili bir işlev görebilecektir. Diğer taraftan, THAAD'ın uçaklar karşısında etkisiz kaldığını belirten farklı analistler, süpersonik hızda uçabilen MiG-31'den gönderilen Kinzhal'ın etkinlik sağlayabileceğini iddia etmektedir. Bu durum tabiatıyla, MiG-31'in Kinzhal'ı ateşlemeden önce ABD kıyılarına yaklaşmasını gerekli kılmaktadır. Kinzhal'ı hedef almak için PAC-2 ve PAC-3 gibi unsurların ise zaman aralığının çok dar olacağı belirtilmektedir (Woolf, 2020: 25; Missile Defense Project, 2018a; Mizokami, 2018).

Uluslararası camia tarafindan en fazla ilgi gören Rus hipersonik füze sistemi ise Avangard'dır. Bu füzenin geliştirilmesiyle ABM Antlaşması'nın sonlanması arasında yakın bir ilişki olduğu için, Avangard'a özel bir parantez açılması gerekmektedir. Putin'in 2002 yılında Rusya'nın HGV tarzı hipersonik

ipuçlarından biri Ağustos 2019'da Nenoksa'daki Füze Test Alanında meydana gelen ve yedi kişinin ölümüne neden olan bir patlamadır. ABD istihbarat yetkililerine göre patlama NATO'nun SSC-X-9 Skyfall (Burevestnik) olarak adlandırdığı bir seyir füzesinin denemesi sırasında gerçekleşmiştir. SSC-X-9 Skyfall'un testleri, Rusya'nın, dünyanın her noktasına ulaşabilecek nükleer güçle çalışan hipersonik seyir füzesi üretme hedefine matuftur. Testlerin başarıya ulaşması hâlinde ABD’nin füze savunma sitemlerine ciddi zorluklar yaşatılabilecektir. $\mathrm{ABD}$, nükleer güçle çalışan füze üretme konusunu zamanında gündemine almışsa da yaşanan zorluklar ve karşılaşılan başarısızlar nedeniyle bu süreci sonlandırmıştır. Rakibinin aksine Rusya ise bu yönde çalışmalar sürdürmeye devam etmektedir. Fakat Nenoksa'daki kazanın gösterdiği gibi, her ne kadar bir Çernobil meydana gelmemişse de, yapılan çalışmalarda ciddi risk ve zorluklarla karşılaşılmaktadır ve nükleer güçle çalışan füze üretiminde başarı sağlanıp sağlanamayacağı konusu hala belirsizliğini korumaktadır (Detaylar için bkz; Sanger ve Kramer, 2019). 
Hipersonik Füzeler ve Stratejik İstikrar:

Rusya-ABD İlişkileri Üzerine Bir İnceleme

silahlar geliştirmesi gerektiği sözü, ABD'nin ABM Antlaşması'ndan çekilme kararına müteakip ilk önemli beyan olmuştur. Kısa süre içinde Rusya, uyguladığ 1 tatbikatlarda HGV araçlarının test uçuşlarını gerçekleştirmeye başlamıştır. Rusya liderliği gerekli adımları atmaya başlamışsa da aynı zamanda ABD ile ABM Antlaşması'nın bir benzerini müzakere edebilmeyi ummuştur. Fakat ABD'nin füze savunma sistemleri geliştirme ve konuşlandırma yönünde verdiği karardan vazgeçmemesi, bu umutları boşa çıkarmıştır. Böylece Avangard'ın gelişim sürecine tekabül eden 2007-2009 arası zaman diliminden itibaren Rusya kararlı adımlarla hipersonik füze geliştirme çabalarını yoğunlaştırmıştır (Starchak, 2019). ABM Antlaşması'nın sonlanmasına ilişkin Putin şu hususun altını çizmiştir: "Bu alanda beraber çalışıp güven ikliminin devamını sağlamaya çalıştık. Bir noktada uzlaşının mümkün olduğunu düşündüysek de bu gerçekleşmedi. Bütün önerilerimiz reddedildi. Ve bundan sonra güvenliğimizi korumak için modern vuruş sistemleri geliştireceğimizi söyledik" (Kremlin, 2018). Aynı konuşmasında Putin, Avangard'ı tanıtırken, hipersonik hızda yol alabilen bu silahın yatay ve dikey olarak güçlü manevra yeteneğine sahip olduğunu vurgulamış ve bu silah karşısında bütün hava ve füze savunma sistemlerinin etkisiz kalacağını belirtmiştir. Böylece nükleer başlık taşıma yeteneğine sahip olan Avangard'ın ICBM'lerin önüne kurulması beklenen füze savunma sistemlerine bir cevap olduğu ve balistik füzeler engellenebilse bile, etkili bir HGV füzesi olan Avangard'ın engellenmesinin mümkün olmadığı mesajı iletilmiştir.

1980'lerde başlayan Yu-70 Albatros programının devamı niteliğinde bir proje olan Avangard (Yu-71), Rusya liderliğinin verdiği bilgiye göre 20 Mach'lık bir hıza ulaşabilmektedir (Claus, 2018: 2). SS-19 ve daha ileriki aşamada RS-28 Sarmat ile taşınması beklenen Avangard'ın $10.000 \mathrm{~km}$ menzile sahip olduğu düşünülmektedir (United Nations Office for Disarmament Affairs, 2019: 11). 26 Aralık 2018'de gerçekleştirilen test uçuşunda Avangard, SS-19 ICBM ile Güney Urallar'daki Dombarovskiy Füze Üssü'nden 5.630 km uzakta Kamchatka Yarımadası'ndaki bir hedefe gönderilmiştir. İstenen sonuçların alınmasına paralel olarak, Aralık 2019 itibariyle Avangard'ın operasyonel hale geldiği ilan edilmiştir. Resmi bilgi verilmemekle birlikte, Orenburg bölgesindeki Dombarovskiy Füze Tümeni'ndeki 13. Alayın Avangard savaş başlığı ile donatılmış iki adet SS-19 ICBM teslim aldığı öngörülmektedir. İlerleyen süreçte 13. Alay’a Avangard savaş 
başlıklarıyla donatılmış dört adet SS-19 ICBM'nin daha teslim edilmesi beklenmektedir (Woolf, 2020: 20-22).

Rusya liderliği, ABD'nin balistik füze savunma sistemlerine karşı Avangard sayesinde ikinci vuruş yeteneğinin engellenemez hale geldiği düşüncesinden hareketle bu silaha stratejik bir önem atfetmektedir (Woolf, 2020, 20). Diğer taraftan Putin, Avangard gibi hipersonik füzeleri dünyaya tanitırken, yaşanan süreci bir ilk olarak takdim etmiştir. Atom bombası, stratejik bombardıman uçağı ve füze sistemlerinde önden giden ülkenin hep ABD olduğunu, Rusya'nın ise arkadan geldiğini hatırlatan Putin, hâlihazırda hipersonik füzelerle ilgili yaşanan sürecin bir ilk olduğunu vurgulamıştır. Bu bağlamda, Avangard gibi kıtalar arası mesafe kat edebilen saldırı amaçlı hipersonik silahlar üreten Rusya'nın rakiplerinin önüne geçtiği aktarılmıştır (TASS, 2020). Rusya'nın bu alanda kat ettiği ilerleme ABD'li yetkililerin gözünden kaçmamıştır. ABD'nin nükleer silahlarından sorumlu Hava Kuvvetleri Generali John Hyten, Rusya'nın geliştirmekte olduğu hipersonik silahlara karşı ABD'nin gerekli savunma sistemlerine sahip olmadığını belirtmiştir. Daha önce Rusya'yı ABD için en ciddi tehdit olarak tanımlayan Hyten, ABD'nin Rus hipersonik füzelerine karşı bir savunma kapasitesi olmadığı için, ancak caydırıcılıkla rakibini durdurabileceğini ifade etmiştir (Macias, 2018). Bir bütünlük içinde ele alındığında, gerek Rus gerekse ABD'li yetkililer, Rusya'nın geliştirdiği Avangard tarzı kıtalar arası hipersonik füzelerin "oyun değiştiren" bir boyut taşıdığını belirtmişlerdir.

Hipersonik silahların, Rusya-ABD arasındaki stratejik dengeyi nasıl etkileyeceğini değerlendirirken, Rusya'nın HGV kategorisindeki hipersonik füzelere ağırlık vermeden önce nasıl bir kapasiteye sahip olduğu anlaşılmalıdır. Kıyaslamalı bir analiz üzerinden, Rusya'nın sahip olduğu envantere hipersonik füzelerin nasıl bir katk1 sunabileceği netleştirilebilecektir. $\mathrm{Bu}$ husus detaylandırılırken, balistik füzelere özel bir parantez açılmalıdır. Öncelikli olarak şu vurgulanmalıdır ki, Rusya ve ABD ölçeğindeki büyük güçler için ICBM ya da SLBM kategorisindeki balistik füzelerin temel işlevi nükleer caydırıcılık tesis etmektir. 3.000 km'ye kadar menzile sahip k1sa ve orta menzilli balistik füzeler devletler açısından esas olarak taktiksel düzeyde işlev görürken, ICBM kategorisindeki balistik füzeler stratejik unsurlar olarak görev ifa etmektedir (Arms Control Association, 2017). Bu itibarla, nükleer savaş başlıklarıyla donatılmış stratejik balistik füzeler, devletlere rakiplerini topyekûn imha etme olanağı dahi 
Hipersonik Füzeler ve Stratejik İstikrar:

Rusya-ABD İlişkileri Üzerine Bir İnceleme

tanımaktadır. ABD-Rusya arasındaki askerî güç dengesi, temel olarak bu denklem üzerine kuruludur.

Nuclear Threat Initiative adlı bir kuruluşun hazırladığı bir çalışma bu tartışma bağlamında faydalı bir bakış açısı sunabilecektir. Nuclear Threat Initiative'in ani bir Rus saldırısında ABD'nin karşılaşacağı tabloyu özetlediği bir çalışma, Speier vd. tarafından şu şekilde bir zaman çizelgesi ile özetlenmektedir (Speier vd., 2017: 16; The Nuclear Threat Initiative, 2017).

0. dakika - Rusya yüzlerce kıtalar arası balistik füzeyi ateşler.

1. dakika - ABD uyduları füzeleri tespit eder.

2. dakika - ABD erken uyarı radarı füzeleri tespit eder.

3. dakika - Kuzey Amerika Hava Savunma Komutanlığı (NORAD) bilgiyi değerlendirir.

4. dakika - NORAD Beyaz Saray’a haber verir.

5. dakika - Rus denizaltılardan yeni balistik füzeler ateşlenir.

7. dakika - ABD Başkanı ile danışmanlarının toplanması sağlanır.

13. dakika - Karara varılır.

15. dakika - Emirler iletilir.

20. dakika - Görevliler emirleri alır, kodları çözümler ve doğrular.

23. dakika - Karşı saldırı dizimi tamamlanır, ABD füzeleri ateşlenir.

25. dakika - Rus kıtalar arası balistik füzeleri hedeflerine ulaşır.

$\mathrm{Bu}$ Zaman Çizelgesi, ani bir balistik füze saldırısında Rusya'nın ABD'ye neler yaşatabileceğine dair net bir tablo ortaya koymaktadır. Balistik füzeler de hipersonik hız limitine ulaşabildiği için, Rusya'nın yüksek sayıda kıtalar arası balistik füzeyi sevk ederek kısa süre içinde ABD'ye büyük bir tahribat yaşatma kapasitesi zaten elinde bulunmaktadır. 2011 senesinde Putin'in, "Amerika'yı yarım saat ya da daha az bir zamanda yok edebilecek yegâne ülkenin Rusya olduğu" ifadesi, yukarıdaki projeksiyonu doğrulamaktadır (Macias, 2016). Keza ABD Genel Kurmay Başkanı Mark A. Milley'nin, henüz Kara Kuvvetleri Komutanı iken, “ABD’yi imha edebilecek tek ülkenin Rusya olduğu” ifadesi, Rusya'nın elindeki kapasitenin ne gibi sonuçlar yaratabileceğinin muhatabı tarafindan da bilindiğini göstermektedir (Leipold, 2015). Bu açıklamaların, Rusya'nın geliştirdiği hipersonik füzelerin uluslararası gündemde yer bulmasından önce yapıldığı göz önüne alınırsa, Rusya'nın zaten balistik füzelerle ABD'ye büyük bir zarar verebileceği, gerek Rus gerekse ABD'li yetkililer tarafından bilinmektedir. 
$\mathrm{Bu}$ tartışma, hipersonik füzelerin etkisiz olduğu şeklinde bir perspektif sunmamaktadır. Zira hipersonik füzeler, hava ve füze savunma sistemlerine ciddi zorluklar yaşatabilecek unsurlar olarak devletlere önemli avantajlar sağlayabilecektir. Örneğin, ABD'nin GBI ve Aegis füze savunma sistemlerine ait önleme füzeleri uzay boşluğunda işlev görebilirken, atmosfer içerisinde, yani daha alçak irtifadan uçuş yapabilen hipersonik füzelere karşı kullanılamamaktadır. Aynı durum Rusya'nın füze savunma önlemleri için de geçerlidir ve bunlar düşük irtifada uçan HGV'ler gibi unsurlar karşısında etkisiz kalmaktadır. Diğer taraftan, atmosferin üst sınırına yakın bölgede etkili olabilen bir sistem olarak THAAD'ın, HGV'leri önleme noktasında işlev görmesi mümkündür (Oelrich, 2020: 40). Aynı şekilde, Patriot hava savunma sistemleri de hipersonik silahlara karşı terminal safha savunmasında işlev görebilecek unsurlardır. Bu bağlamda, THAAD ve Patriot gibi "nokta savunması" yapabilecek unsurların hipersonik füzelere karşı kullanılması mümkündür. ABD açısından bakıldığında, stratejik öneme haiz hedeflerin, bu ülkenin hâlihazırdaki hava ve füze savunma unsurları ile sınırlı oranda korunmasının yapılması olanak dâhilindedir. Fakat ABD ana karasının tamamını koruyabilmek için ulaşılması güç sayıda THAAD ve Patriot sistemine ihtiyacı vardır (Acton, 2018). Aslında aynı durum balistik füzeler için de geçerlidir. Sınırlı sayıda balistik füzeye karşı ABD'nin füze savunma altyapısı bir işlev görebilecek olsa da Rusya gibi geniş ICBM ve SLBM envanterine sahip bir ülkeye karşı tam teşekküllü bir füze savunması gerçekleștirmek imkân dışıdır.

Rusya'nın envanterinde bulundurduğu modern ICBM'ler, çoklu ve manevra yapabilen yeniden giriş araçları (yani harp başlıkları) taşıyan ve rakip ülkenin savunma sistemlerini hedef şaşırtarak ekarte etmek için kullanılan çeşitli aldatma önlemlerini (penetration aids) bünyesinde barındıran karmaşık sistemlerdir (Kofman, 2019). Rusya, elindeki ICBM'leri ve sahte hedef taktiklerini uygulayarak, "tehdit bulutu" yaratmak suretiyle ABD'nin hava savunma önlemlerini atlatma ve delme yeteneğine sahiptir (Kofman, 2019). Hâlihazırda muhtelif say1da SS-18 Satan, SS-27 Topol-M, SS-25 Topol, SS-19 Stiletto ve RS24 Yars füzelerini elinde bulunduran ve operasyonel hale gelmeyi bekleyen RS-26 Rubezh ve RS-28 Sarmat füzelerini de envanterine katacak olan Rusya, ICBM bakımından tartışmasız şekilde güçlü bir envantere sahiptir (Missile Defense Project, 2018b). Bu envanterle Rusya, ABD'yi nükleer savaş başlığı taşıyan yeterince yüksek sayıda balistik füzeyle vurma imkânına zaten sahiptir. 
Hipersonik Füzeler ve Stratejik İstikrar:

Rusya-ABD İlişkileri Üzerine Bir İnceleme

$\mathrm{Bu}$ tartışmanın ortaya koymaya çalıştığı gibi, hipersonik füzeler, Soğuk Savaş'ın bir mirası olan Dehşet Dengesi'ni bozacak unsurlar değildir. Her ne kadar ABM Antlaşması sonlanmışsa da Rusya-ABD arasında stratejik nükleer silahlar üzerine kurulu askerî güç dengesi geçerliliğini korumaktadır. Rusya'nın Avangard gibi hipersonik füzeler geliştirmeyi başarması geniş yankı uyandırsa da bu silahlar, Rusya'nın stratejik nükleer silah envanterine "oyun değiştirecek" unsurlar olarak değil, nükleer caydırıcılığına "ilave bir katman" ekleyecek unsurlar olarak dâhil olmaktadır. Öte yandan ilerleyen dönemde ABD'nin füze savunma alanında yeni yetenekler geliştirmesi senaryosuna karşı Rusya, hipersonik silahlara yaptığı yatırımla ilave bir güvence elde edebilecektir.

\section{Hipersonik Füzeler ve Konvansiyonelden Nükleer Aşamaya Geçiş Riski}

Yukarıda tartışıldığı üzere, ABD ile olan rekabetinde Rusya açısından hipersonik füzelerin temel işlevi nükleer vuruş kapasitesi ile ilintilidir. ABD açısından bakıldığında ise farklı bir resim ortaya çıkmaktadır. Zira bu ülke hipersonik füzeleri, konvansiyonel vuruş yeteneğini güçlendirmek amaciyla geliştirmeye çalışmaktadır (Acton, 2018). Yakın zamana ait bir okuma yapıldığında, ABD'nin uzun yıllardır konvansiyonel unsurlarla hedef imhası gerçekleştirme yönünde adımlar atmakta olduğu görülecektir. Bu kapsamda kilometre taşı mahiyetindeki inisiyatif "Ani Küresel Vuruş" (PGS) isimli savunma konseptidir.

2003 yılında Savunma Bakanlığı'nın geliştirdiği PGS, ABD’nin ileri mevcudiyet işlevi gören üslerinin yetersiz kalabileceği durumlarda, kendi ana karasından konvansiyonel vuruşla hasım unsurları hedef alma düşüncesini yansıtmıştır. Bu strateji, yüksek tehdit içeren ve mobil olabilen unsurların ABD'ye zarar verme imkânlarının önüne set çekmeyi amaçlamaktadır. Normalde günler alabilecek operasyon hazırlıkları bir kenara bırakılarak, dakika ya da saatle ölçülebilecek bir zaman diliminde hedef imhasının gerçekleştirilmesi planlanmıştır. PGS konsepti çerçevesinde, bir saatten az bir sürede hasım unsurları etkisiz hale getirebilme yeteneğine ulaşmak, hipersonik silahları önemli bir konuma taşımıştır. Örneğin uçakların kullanılması durumunda, gerek hedefe ulaşmanın daha fazla zaman alacak olması, gerekse operasyonun gerçekleşeceği ülkenin hava savunma sistemlerine yakalanılması gibi risk ve engeller nedeniyle istenen verimin alınamayacağı düşünülmüştür. Daha yavaş uçan seyir füzelerinin kullanılması 
durumunda ise kritik hedeflerin zamanında vurulamaması riski hesap edilmiştir. $\mathrm{Bu}$ itibarla, hipersonik füzelerle, silah depoları, kitle imha silahları, komuta-kontrol merkezleri ya da siyasi karar mercileri gibi kritik unsurların hızlı ve etkili bir şekilde hedef alınabileceği değerlendirilmiştir (Woolf, 2019: 2-8).

2003'te tanzim edilen bu doktrin üzerinde 11 Eylül 2001 saldırılarının etkisi açıktır. Zira devletten ziyade devlet harici bir aktörün saldırısına maruz kalan ABD, esnek, hızlı hareket edebilen ve karmaşık bir operasyonel yapıya sahip olan terör unsurlarını (Bousquet, 2011) aynı hız, esneklik ve etkinlikle imha edebilme yeteneğine ihtiyaç duymuştur. Tehdit algısını devletlerden ziyade devlet harici aktörlerin şekillendirmesi, savunma konseptinde paradigmatik bir değişikliği beraberinde getirmiştir. Bu paradigma, yaklaşık olarak 2010 yılına kadar devam etmiştir.

11 Eylül atmosferinin gerilemesi ve özellikle büyük güç rekabetinin güçlenmesine paralel olarak ise güvenlik algısında tekrardan bir değişiklik meydana gelmiştir. 2011 yılında Obama döneminde hayata geçen Stratejik Pivot konsepti gereğince ABD, askerî unsurlarını Pasifik'e yönlendirilmeye başlamış ve böylece Güney Çin Denizi'nde etki alanını genişletmekte olan Çin'i daha etkili bir şekilde dengelenmeyi amaçlamıştır. Güçlenmekte olan büyük güçler arası artmakta olan rekabetin diğer bacağını ise Rusya teşkil etmiştir. 2018 senesinde Pentagon'un Nükleer Duruş Değerlendirmesi isimli belgesinde, 2010 yılından geçerli olmak üzere büyük güçler arasındaki rekabetin kızışmakta olduğu belirtilirken, Rusya'ya özel bir vurgu yapılmıştır. 2013'te başlayan Ukrayna krizine referansla Rusya'nın, nükleer silah tehdidinden güç olarak Avrupa'nın haritasını zorla değiştiren ve bölge ülkelerini baskılayan adımlar attığı vurgulanmıştır (Department of Defense, 2018: 6). $\mathrm{Bu}$ gelişmelerin NATO coğrafyasına yakın alanlarda yaşanıyor olması nedeniyle, bir NATO ülkesi olan ABD'nin de sorumluluk taşıdığının altı çizilmiştir (Department of Defense, 2018: 30-31).

Rusya merkezli olarak ABD'nin güvenlik tasavvuru bir bütünlük içinde ele alındığında, Rusya'nın stratejik nükleer silahlarla ABD'yi hedef alabilmesi önemli bir güvenlik riskidir. Fakat aynı zamanda, NATO coğrafyasına yakınlığı nedeniyle Rusya'nın ABD müttefiklerini tehdit edebilme olasılığı da ABD tarafından dikkate alınmaktadır. Ortadaki riskler çerçevesinde $\mathrm{ABD}$, muhtelif senaryolara karşı hipersonik füzelerin işlev görebileceği sonucuna ulaşmıştır. Zikredildiği gibi, hipersonik füzeler $\mathrm{ABD}$ açısından esas itibariyle nükleer olmayan vuruş yeteneğine sahip olmak için önemlidir. Soğuk Savaş yıllarından itibaren ABD hipersonik 
Hipersonik Füzeler ve Stratejik İstikrar:

Rusya-ABD İlişkileri Üzerine Bir İnceleme

araçlar geliştirme konusunda avantajlı bir konumda olmuşsa da Rusya'nın bu açığ hızla kapatması, ABD'yi yeni adımlar atmaya sevk etmiştir. Bu itibarla 2010'ların başından itibaren ABD hipersonik sistemler geliştirme konusunda yeni denemeler gerçekleştirmeye başlamıştır. Fakat bu süreç sorunsuz ilerlememiştir. Örneğin, yaklaşık 20 Mach'lık bir hıza ulaşması amaçlanan Hipersonik Teknoloji Aracı (HTV) adlı sistemin 2010 ve 2011'deki denemeleri başarısızlıkla sonuçlanmıştır (Gubrud, 2015: 2). HTV serisinde bir diğer model olan HTV-2'nin performansında da çeşitli sorunlar yaşanmıştır. Taşııııı Minotaur IV füzesinin HTV-2'yi istenen seyir düzlemine taşımasında ve HTV-2'nin roket motorundan ayrılmasında başarı sağlanmışsa da aracın 30 dakikada $6.600 \mathrm{~km}$ mesafe kat etmesi hedefine ulaşılamamıştır. Diğer taraftan, 12 Mach'lık hız limiti ile HTV serisinden daha yavaş bir model olan "Gelişmiş Hipersonik Silaha” (AHW) matuf olarak 2011 y1lında bir başka test gerçekleştirilmiştir. Donanma'nın Polaris balistik füzesinden türetilen ve Strategic Target System (STARS) olarak bilinen füze sistemiyle gönderilen AHW, Hawaii'deki Pasifik Füze Test Sahası Tesisi'nden Kwajalein Adası'na kadar 3.860 km'lik bir yol kat edebilmiştir. AHW'nun koni şeklinde bir dizayna sahip olması, yüzeyindeki ısıyı daha kolay dağıtmasına imkân tanımıştır. Böylece, kanat profiline sahip HTV-2'nin karşılaştığı aşırı 1sınma sorunundan muaf kalabilmiştir. AHW, 2014 senesinde yeni test sırasında ise firlatma rampasından ayrıldıktan sonra roket motorunda yaşanan bir sorun nedeniyle infilak etmiştir. 2017 yılında ise ABD Donanması, SLBM vasitasıyla gönderilen AHW'nun yeni bir denemesini gerçekleştirmiş ve başarılı sonuç alındığı bildirilmiştir (United Nations Office for Disarmament Affairs, 2019: 8; Woolf, 2019: 10-16).

$\mathrm{Bu}$ girişimlerden sonra, Amerikan Kara ve Deniz Kuvvetleri'nin ortak kullanımı için tasarlanan Common Hypersonic Glide Body (C-HGB) adlı farklı bir hipersonik füze modelinin çalışmalanı başlamıştır. Ekim 2017'de C-HGB'nin ilk testi başarılı bir şekilde sonuçlanmış ve bu başarı Mart 2020'de gerçekleştirilen yeni bir test ile taçlandırılmıştır. C-HGB'nin Kara Kuvvetleri'nin ihtiyaçlarına göre dizayn edilmiş modelinin 2023, denizaltılardan firlatılacak Deniz Kuvvetleri türevinin ise 2025 'ten sonra kullanıma girmesi hedeflenmektedir. ABD Hava Kuvvetleri kullanımına yönelik olaraksa Havadan Ateşlenen Hızlı Karşılık Silahı (ARRW) ve Hava Soluyan Hipersonik Darbe Silahı (Hypersonic Strike Weapon Air Breathing) adlı iki yeni sistemin çalışmaları devam etmektedir (Freedberg, 2020). 
Bütün bu çabaların konvansiyonel vuruş kapasitesini geliştirmek isteyen ABD için yadsınamaz bir önemi bulunmaktadır. Uzun menzilli sistemler ile hedef imhası gerçekleştirmek ve bunu yüksek kesinlik ile icra etmek için yetkin unsurlara ihtiyaç duyulmaktadır. Kıyaslamalı bir açıdan bakıldığında, isabetlilik bakımından balistik füzelerin yaklaşık 100 metrelik bir hata payına sahip olduğu ifade edilmektedir. Devletlerin konvansiyonel savaş başlıkları ile bir saldırı gerçekleştirmeyi düşünmeleri durumunda ise isabet hassasiyeti bakımından çok daha yetkin sistemlere ihtiyaçları vardır. Zira 100 metrelik bir hata payı, nokta atışı ile imha edilmesi istenen bir hedef için önemli bir sapma oranıdır. Bu bağlamda yüksek isabetlilik ve manevra yetenekleriyle hipersonik füzeler, konvansiyonel başlıklarla hedef imhası için adeta biçilmiş kaftan olarak tanımlanabilecek silahlardır. Taşıma roketinden ayrıldıktan sonra HGV'ler, aerodinamik kaldırma kuvvetinin yardımıyla havada süzülerek binlerce kilometre yol kat edebilmekte ve mükemmelle yakın bir kesinlikle hedefe ulaşabilmektedir (Acton, 2013: 5-6). Bu hususlar, ABD için hipersonik füzelerin nasıl bir işlev göreceği sorusuna bir cevap teşkil etmektedir. Güdümlü silah sistemleri geliştirme konusundaki yetkinliğiyle $\mathrm{ABD}$, hipersonik füzelerle konvansiyonel vuruş kapasitesini yükseltmeyi ve erimini genişletmeyi amaçlamaktadır.

Öte yandan hipersonik silahlarla ilgili ABD'nin izlediği bu politikanın, potansiyel tehlikelere kapı aralaması da kuvvetle muhtemeldir. Zira muhatap devletlerin, ABD menşeli bir hipersonik füzenin konvansiyonel ya da nükleer başlıktan hangisini taşıdığını kestirebilme kapasiteleri sınırlıdır. Yaşanabilecek karışıklıklar, PGS programı için düğmeye basıldığı andan itibaren zihinleri kurcalamıştır. Hipersonik silahların gündeme gelmesinden önce, normalde nükleer başlık taşıyan modifiye edilmiş balistik füzelerle küresel vuruş gerçekleştirilmesi fikri ortaya sürüldüğünde, ABD Kongresi potansiyel riskler nedeniyle bu öneriyi reddetmiştir (Oelrich, 2020: 38). Bu süreçte, 2006 senesinde George W. Bush yönetimi, ABD denizaltılarınca taşınan Trident tipi SLBM'lerin konvansiyonel başlıklarla donatılarak PGS misyonuna uyarlanmasını planlamış, ancak bu plan ABD Kongresi'nin muhalefetiyle karşılaşmıştır. Bunun nedeni, muhatap ülkelerin normalde nükleer başlık taşıyan Trident füzelerinin artık konvansiyonel mi yoksa nükleer başlık mı taşıdığını kestiremeyecek olmaları ve bunun sonucunda nükleer silahla ABD'ye karşılık vermeleri riski olmuştur. Diğer taraftan ABD yönetimi gibi ABD Kongresi de, rakip devletlerin erişimi engelleme /bölgeye sokmama (A2/AD) kabiliyetlerini güçlendirme çabalarının, Çin gibi ülkelerin uydu-savar füze 
Hipersonik Füzeler ve Stratejik İstikrar:

Rusya-ABD İlişkileri Üzerine Bir İnceleme

sistemlerine yaptıkları yatırımın, İran ve Kuzey Kore'den kaynaklanan tehditlerin altını çizerek, ABD'nin PGS kapasitesini güçlendirmesi gerektiğine inanmıştır (Acton, 2013: 1-2). PGS programının kendisine karş1 çıkmaktan ziyade Kongre, balistik füzelerin taşıdığı savaş başlıklarından kaynaklanan yanlış anlamalar nedeniyle Çin ve Rusya gibi ülkelerle nükleer bir savaşa girilmesi riskine dikkat çekmiştir (Oelrich, 2020: 38).

Hipersonik füze sistemleri bu tehlikeyi ortadan kaldırmadığ 1 gibi, mevcut belirsizliği daha da arttırabilecek potansiyel bir risk kaynağıdır. Bu riski irdelerken, hipersonik füzelerin yüksek manevra yetenekleri ve düşük irtifadan uçabilme kabiliyetlerinin özellikle altı çizilmelidir. Hipersonik füzelerin en önemli dezavantaj1, hedef öngörülebilirliğini azaltmaları sebebiyle potansiyel bir istikrarsızlık kaynağı olmalarıdır. Parabolik bir seyir izleyen balistik füzeler, hangi alanın hedef alındığı konusunda saldırıya maruz kalan ülkelere belirli bir öngörülebilirlik sağlamaktadır. Fakat etkili manevra yeteneğine sahip, yayılma/süzülme hareketleri yapabilen HGV kategorisindeki hipersonik araçların hedeflerinin öngörülebilirliği çok daha azdır. Bir saldırı durumunda, yarı yolda hedef değiştirme amaçlı manevra yapma kabiliyetine sahip bu araçların, ateşlendiklerinde birden fazla ülke tarafindan tehdit olarak algılanmaları mümkündür. Örneğin, ABD tarafindan Kuzey Kore'ye gönderilen bir hipersonik füze, Çin'e asıl olarak kendisinin hedef alındığını düşündürtebilir ve bu düşünceden hareketle Çin'in ABD'ye misillemede bulunması sonucu doğabilir. Aynı durum Rusya için de geçerlidir. Rusya, ABD'nin İran'ı hedef alarak yolladığ 1 bir hipersonik füzenin, asıl olarak kendisini hedef aldığı endişesine kapılabilir (Lele, 2019: 56).

ABD'nin konvansiyonel hassas güdümlü silahlarla Rusya'nın (ve ayrıca Çin'in) nükleer silahlarını hedef alma ihtimali belirli bir süredir bu ülkelerin hissettikleri bir endişedir (Acton, 2013: 15). Hâlihazırda gerçekleşen denemelerin tamamlanması ve ABD’nin gelişmiş hipersonik füzelerini tam teşekküllü olarak envanterine dâhil etmesi durumunda, potansiyel tehlikelerin güçlenmesi ciddi bir ihtimaldir. Nasıl olsa nükleer başlık kullanılmadığından hareketle ABD’nin sergileyebileceği ihtiyatsız eylemler, saldırıya maruz kalan ülkenin kendi stratejik unsurlarına bir müdahale gerçekleşmekte olduğu kaygısından hareketle nükleer misillemesine sebep olabilir. Nitekim bu yöndeki potansiyel tehlikeler ABD askerî yetkilileri tarafından da fark edilmiş ve belirsizliği gidermek amacıyla çeşitli 
öneriler sunulmuştur. Örneğin ABD Hava Kuvvetleri yetkilileri, konvansiyonel savaş başlıkları ile donatılmış füzelerin, nükleer muadillerinden uzak alanlarda, ayrı üslerde muhafaza edilmesini önermişlerdir. Bu bağlamda ABD'nin doğu ve batı kıyılarındaki belirli askerî alanların nükleer olmayan alanlar olarak belirlenmesi önerilmiş ve bu alanlardaki mobil firlatıcılara veya toprağa yarı gömülü füze firlatma rampalarına sadece konvansiyonel başlık taşıyan füzelerin yerleştirilmesi teklif edilmiştir. Lokasyon olarak ise ABD'nin batısında Vandenberg hava üssü, doğusunda ise Cape Canaveral üssü önerilmiştir (Woolf, 2019: 11).

Rusya özelinde değerlendirildiğinde, bu şekilde bir adımın teskin edici olmaktan uzak olduğu vurgulanmalıdır. Hâlihazırda Rusya ve ABD arasında ABM Antlaşması'nın sonlanmasından itibaren süregelen güvensizlik ortamı, ABD'nin INF Antlaşması'ndan çekilmesiyle birlikte iyice derinleşmiştir. Rusya açısından irdelendiğinde, ABD'nin tek taraflı güvencelerle nükleer-konvansiyonel ayrımı konusunda bilgilendirici adımlar atmasının ikna edici bulunmaktan uzak olduğu açıktır. Bazı yazarlar, ABD’nin hipersonik füze programının nükleer olmayan savaş başlıkları baz alınarak ilerlediği ve taktik amaçlı kullanılmasının düşünüldüğü görüşü üzerinden iyimser bir yaklaşım sergileseler de, bunun rakip aktörlerin kaygılarını azaltması zayıf bir ihtimaldir (Wilkening, 2019: 139). Örneğin, barış dönemlerinde nükleer-konvansiyonel ayrımını netleştirme amaçlı güven arttırıcı adımlar atılabilse de kriz ya da çatışma anlarında nükleer başlıkların mahiyeti belli olmayan sevk sistemlerine yüklenmesiyle, bu ayrımın ortadan kalkması söz konusu olabilir (Acton, 2020: 30-31). Bir diğer önemli nokta olarak, nükleer başlıklarla olduğu gibi, konvansiyonel vuruş amacıyla kullanılan başlıklarla da stratejik hedeflerin imha edilebileceği gözden kaçırılmamalıdır. Bir füze, bir ülkenin nükleer silahları veya komuta-kontrol-haberleşme altyapısı gibi stratejik unsurlarını hedef aldığında, füze başlığı ister konvansiyonel ister nükleer olsun, saldırıya muhatap kalan Rusya gibi nükleer güçler, mütecaviz eyleme stratejik (nükleer) misilleme ile karşıllk verebilir (United Nations Office for Disarmament Affairs, 2019: 21).

$\mathrm{Bu}$ riskler karşısında, hipersonik füzelerle ilgili nükleer-konvansiyonel ayrımını esas alan bir düzenlemenin hayata geçirilmesi, nükleer çatışma tehdidini azaltabilecek faydalı bir adım olacaktır. ABD'nin envanterinde bulundurduğu hipersonik füze sistemleri üzerinde Rusya'nın kontrol sağlaması mümkün olmadığına göre, teskin edici yegâne adım, hipersonik füzelerin stratejik dengeyi 
Hipersonik Füzeler ve Stratejik İstikrar:

Rusya-ABD İlişkileri Üzerine Bir İnceleme

tahrip edecek şekilde konvansiyonel başlıklarla donatılmayacağı yönünde bir anlaşmanın ve doğrulama/denetim mekanizmalarının hayata geçirilmesidir. Bu sayede, Soğuk Savaş zamanından beri ICBM ve SLBM unsurları ile tesis edilen "çatışmasızlık üzerine kurulu stratejik istikrarın” devamını sağlamak mümkündür. Öte yandan, burada ifade edilen önerinin uygulanması noktasında bazı zorluklar olduğu da açıktır. ABD’nin PGS programı göz önüne alındığında, konvansiyonel hipersonik füzelerden vazgeçilmesi anlamına gelecek bir mutabakat, bu programın akamete uğramasına neden olacaktır. ABD'nin hipersonik füzeleri konvansiyonel başlıklarla donatma fikrinden vazgeçmemesi ise Rusya'y1 her daim tehdit edecektir. Böylece uzlaşmanın önüne engel çıkaran farklılıklar nihai bir çözümü zorlaştırmaktadır.

Ortadaki zorluklara rağmen, stratejik dengeyi muhafaza edebilmek için rekabeti nükleer seviyede tutma yolu bulabilmek kilit önemdedir. Bunu sağlayabilmenin yolu ise belli başlı adımlarla yapıcı bir ortamın tesis edilmesidir. Örneğin hipersonik silahların üretilmesi için gerekli teknolojisinin kontrolsüz bir şekilde yayılmasının önlenmesi, bu alanda başı çeken iki ülke olarak ABD ve Rusya'nın her ikisi için de önem arz etmektedir. Rusya özelinde hipersonik unsurların yayılmasının önlenmesi, doğudan ya da batıdan gelebilecek olası saldırıların engellenmesi için önemlidir. Örneğin her ikisi de birer ABD müttefiki olan Japonya ve Polonya'nın hipersonik füzelere erişmesi durumunda, Rusya'nın doğu ve batı cephesinden hissettiği tehdidin dozunda kaçınılmaz olarak bir artış meydana gelecektir (Speier, 2017: 40). Müşterek kaygılar çerçevesinde ortak çalışma alanları bulmak ve bunu ikili ya da Çin'in de dâhil olduğu çok taraflı anlaşmalarla taçlandırmak, potansiyel riskleri azaltmaya yardımcı olacaktır. Karşılıklı atılabilecek yapıcı adımlarla, hipersonik füzelerin Dehşet Dengesi üzerine kurulu stratejik istikrarı tehdit etmesi önlenebilir. Konvansiyonel hipersonik füzelerle nükleer tırmanmaya neden olabilecek bir istikrarsızlı̆̆ın engellenmesi, hem ABD hem de Rusya ve onlarla birlikte dünyanın geri kalanının çıkarınadır.

\section{Sonuç}

$\mathrm{Bu}$ çalışmada hipersonik füzelerin Rusya-ABD arasındaki stratejik istikrarı nasıl etkileyebileceği sorusuna yanıt aranmıştır. Askerî-stratejik konu başlıkları arasında hipersonik füzeler önem kazanmaya başladığı için, uluslararası sistemde 
iki büyük nükleer güç olan Rusya ve $\mathrm{ABD}$ arasındaki ilişki mercek altına alınarak, hipersonik füzelerin potansiyel etkileri sorgulanmıştır. $\mathrm{Bu}$ yönde bir sorgulama, hipersonik füzelerin sahip oldukları özellikler nedeniyle, uluslararası güvenlik üzerinde yaratabileceği etkilerin anlaşılması bakımından önemli bir gerekliliktir. Zira sesten en az beş kat hızla hareket edebilen ve ayrıca güçlü manevra yeteneği ve görece alçak irtifalardan uçabilme özelliğine sahip olan hipersonik füzeler, hâlihazırdaki hava ve füze savunma sistemlerine ciddi zorluklar yaşatabilecek sistemlerdir. $\mathrm{Bu}$ sistemlerin olası etkilerini incelerken, hipersonik füzeleri devletlerin hangi güvenlik ihtiyacına binaen envanterlerine dâhil etmek istediklerinin netleştirilmesi gerekmektedir. Zira hipersonik füzeler kullanım amaçlarına bağlı olarak farklı sonuçlar yaratabilecek olup, bu füzelere sahip olmak isteyen devletlerin konvansiyonel ya da (bu devletler nükleer silaha sahipseler) nükleer vuruş kapasitesini güçlendirme opsiyonlarından hangisini önceledikleri önemli bir sorudur. Bu soruya yanıt bulmak amaciyla, Rusya'nın hipersonik füzeleri nükleer, ABD'nin ise konvansiyonel başlıklarla donatmak istemesi dikkate alınarak, bu iki ülke arasındaki askerî rekabet üzerinde hipersonik füzelerin olası etkileri incelenmiştir.

Rusya özelinde irdelendiğinde ulaşılan sonuç, Rusya-ABD ilişkilerinde Soğuk Savaş zamanında tesis edilen "Dehşet Dengesi” üzerinde hipersonik füzelerin kayda değer bir etki yaratmadığıdır. Rusya, hâlihazırda elinde bulundurduğu geniş stratejik füze envanteri ile ABD'nin hava savunma altyapısını ekarte edebilecek bir kapasiteye sahip bulunmaktadır. Bunun anlamı, ICBM ve SLBM unsurları ile Rusya'nın ABD’yi topyekûn imha etme kabiliyetine zaten sahip olduğudur. Hipersonik füzelerin ise bu dengeyi etkilemeleri muhtemel görünmemektedir. Hipersonik füzelerden bağımsız olarak, Rusya'nın elindeki geniş stratejik füze envanterinin nükleer vuruş yeteneği bakımından bu ülkeyi güçlü bir konuma taşıdığı vurgulanmıştır. $\mathrm{Bu}$ tartışmadan, nükleer başlık taşıyabilen hipersonik füzelerin işlevsiz olduğu gibi bir sonuca ulaşılmamıştır. Zira Rusya'nın büyük önem atfettiği nükleer caydırıcılık faktörüne hipersonik füzeler ilave bir katman olarak eklenmektedir. Fakat bu husus, Rusya-ABD arasındaki stratejik dengede hipersonik silahları (Rusya açısından) "oyun değiştirecek" silahlar hâline getirmemektedir. Öte yandan, ABD'nin füze savunma alanında gelecekte yapması muhtemel teknolojik ve yetenek sıçramaları karşısında Rusya, 
Hipersonik Füzeler ve Stratejik İstikrar:

Rusya-ABD İlişkileri Üzerine Bir İnceleme

stratejik nükleer füzeleri sayesinde caydırıcılığını sürdürme güvencesi elde etmektedir.

Rusya'dan farklı olarak hipersonik füzelerin $\mathrm{ABD}$ için temel işlevi konvansiyonel vuruş yeteneğini güçlendirme çabası ile ilintilidir. 11 Eylül saldırılarından itibaren ABD, hasım unsurları kendi ana karasından hedef almasına imkân tanıyacak ve böylece küresel vuruş kapasitesini güçlendirecek hipersonik silah geliştirme çalışmalarına ağırlık vermiştir. ABD açısından, 2010'dan itibaren Çin ve Rusya ile büyük güç rekabetinin önem kazanmasıyla, konvansiyonel vuruş programı, bu rekabeti esas alan bir çerçevede revize edilmiş ve hipersonik füzeler de bu stratejinin bir parçası olmuştur. Fakat ABD’nin amaçladığı gibi, hipersonik füzelerin konvansiyonel başlıkla donatılması, Rusya ile olan rekabette tehlikeli gelişmelere neden olabilecek riskleri beraberinde getirmektedir. Bu risklerden ilki, balistik füzeler özelinde olduğu gibi, hipersonik füzeler özelinde de nükleerkonvansiyonel başlık ayrımının saldırıya uğrayan ülke tarafından yapılmasının zorluğudur. Böylece konvansiyonel bir saldırıya nükleer silahla karşılık verilmesi riski söz konusudur. İkinci bir risk, hâlihazırda Rusya, ABD'nin hassas güdümlü silahlarla Rus stratejik unsurlarını hedef alabileceği kaygısını hissederken, hipersonik füzelerin bu kaygıyı daha da arttıracak olmasıdır. Hız, manevra, alçak irtifadan uçuş yeteneğine ve yüksek isabet oranına sahip olan hipersonik füzeler, binlerce kilometre yol kat edebilmektedir. ABD, hipersonik füzelerle farkl devletleri hedef almak istese bile, Rusya'nın söz konusu saldırının esas olarak kendisini hedef aldığını düşünmesi, bu düşünceden hareketle misillemede bulunması ve bu gelişmelerin öngörülemeyen risklere neden olması muhtemeldir. Bir diğer risk ise ABD konvansiyonel başlıkla bir hipersonik saldırı gerçekleştirse dahi, bunun stratejik sonuçlar doğurması ihtimalidir. Bu nedenle, özellikle nükleer altyapısına hizmet eden stratejik unsurların saldırıya uğraması durumunda Rusya'nın nükleer misilleme seçeneğine başvurması gibi bir ihtimal söz konusu olabilecektir.

$\mathrm{Bu}$ tartışmalardan çıkan sonuç, hipersonik füzelerin Rusya-ABD ilişkileri üzerinde istikrarsızlık yaratma ihtimalinin olduğu; fakat bu ihtimalin nükleer unsurlardan değil konvansiyonel unsurlardan kaynaklandığıdır. Rusya-ABD ilişkisi baz alınarak çalışmanın iki hipotezini destekleyen bulgular şu şekilde özetlenebilir: hipersonik füzelerin nükleer amaçla kullanımı düşünülürse, bunun stratejik denge üzerinde kayda değer bir etkisi bulunmamaktadır. Hâlihazırda gerek Rusya gerekse 
$\mathrm{ABD}$, muhatabının füze savunma önlemlerini delebilecek stratejik füzelere sahiptir. Bu bağlamda, hipersonik füzelerin "Dehşet Dengesi" üzerinde "oyun değiştiren" bir etkisi bulunmamaktadır. Fakat hipersonik füzelerin konvansiyonel vuruş yeteneğini güçlendirmek amacıyla kullanımı düşünüldüğünde, bunun stratejik istikrar üzerinde tahrip edici etkileri olabilir. Hipersonik silahlar nükleer değil konvansiyonel başlık taşıdığı gerekçesinden hareketle sergilenebilecek ihtiyatsız eylemler, konvansiyonelden nükleer seviyeye tırmanma riskini doğurmaktadır. Bu nedenle, Rusya ve $\mathrm{ABD}$ gibi iki başat askerî gücün ilişkilerindeki stratejik dengenin muhafazası için, hipersonik silahların konvansiyonel başlıkla kullanılmayacağı yönünde bir anlaşmaya varılması büyük önem taşımaktadır. İki büyük güç arasındaki rekabeti nükleer silahlar seviyesinde tutabilmek, stratejik istikrar için kritik bir ön koşuldur.

\section{Extended Summary}

Among various weapons systems that create "game changing effects", hypersonic missiles have garnered increasing attention internationally. Academics, experts and policy-makers have all grappled with the potential impacts of such highly-capable weapon systems as hypersonic missiles given their ability to overwhelm the existing defense systems. These weapons derive their effectiveness from their ability to travel at least five times greater than the speed of sound, while flying at low altitude and ably maneuvering to overcome missile defenses.

The weapon systems that are classified as hypersonic missiles are divided into two main categories, which are hypersonic cruise missiles (HCM) and hypersonic glide vehicles (HGV). Although HCMs constitute a qualitative leap in terms of the effectiveness of cruise missiles, attention has mainly focused on those missiles known as the HGVs. This is because HGVs are argued to possess the required qualitative characteristics to replace intercontinental ballistic missiles (ICBM), thus potentially generating impacts on international stability. Indeed, although ballistic missiles can also travel at hypersonic speeds, HGVs follow a non-ballistic trajectory and perform fast maneuvers to avoid interception while travelling intercontinental distances at hypersonic speeds.

Given the effectiveness of hypersonic missiles, it is imperative to assess their potential impacts on strategic balance. Similar to ballistic or cruise missiles, hypersonic missiles can be armed with conventional or nuclear warheads. This 
Hipersonik Füzeler ve Stratejik İstikrar:

Rusya-ABD İlişkileri Üzerine Bir İnceleme

makes it necessary to offer two case studies to measure the impact of these weapons. In this manuscript, this was achieved by focusing on the strategic relationship between Russia and the US in the light of their respective hypersonic programs. As military rivals, these two states have diverging goals regarding their wish to develop hypersonic missiles. While Russia invests in these missiles to bolster its strategic nuclear arsenal, the US intends to utilize them for conventional purposes.

Given its rivalry with the US, Russia has long been dismayed by its counterpart's withdrawal from the ABM Treaty, which purportedly threatens Russia's strategic arsenal. This concern has been highlighted by the Russian leadership as the main reason for Russia to begin to develop hypersonic systems. In its endeavor to build missiles that can overcome defense systems, Russia has introduced a number of hypersonic weapons such as Kinzhal, Zircon and Avangard, the last of which has been the center of attention. Despite much praise bestowed upon Russia for developing such a weapon as Avangard (an HGV type weapon), it is unlikely to alter the strategic balance between Russia and the US. This is because Russia already possesses a formidable strategic missile arsenal with which to inflict intolerable harm on the US. Russia's large ICBM inventory provides it with the capability to fire hundreds of nuclear-armed ICBMs and SLBMs against the US and in the face of such a salvo, the U.S air defense infrastructure would easily be overwhelmed. Hence, although hypersonic missiles may help Russia bolster its nuclear deterrence, their ability to upset the strategic stability between the two states is rather limited.

As opposed to nuclear armed-hypersonic weapons, conventionally-armed ones are a potential source of trouble as far as the preservation of strategic stability between Russia and the US is concerned. As the US pursuit of hypersonic weapons is geared towards the goal of bolstering its conventional strike capability, this could pose a number of significant security risks for Russia. For one, it may be unlikely for Russia to distinguish between conventional and nuclear-armed hypersonic missiles, when it detects the flight of such weapons close to its borders. Even if the US aims its weapons towards different targets, the fact that HGV type weapons are capable of flying thousands of miles before they dive onto their target may create unintended consequences such as Russia's conventional or nuclear retaliation. The 
risks would be compounded if there is a volatile security environment, thus complicating threat assessments.

It is concluded in this article in the context of Russia-US relations that strategic stability faces less risk if hypersonic missiles are intended for nuclear purposes. As a product of the Cold War, "Mutually Assured Destruction" between Russia and the US is still in place thanks to the presence of ICBM inventories, and hypersonic weapons are unlikely to upset this relationship. On the other hand, great risks may arise if the US, the side that seeks to utilize hypersonic systems for conventional purposes, goes ahead with its intention to develop non-nuclear hypersonic strike systems. Imprudent behavior with conventionally-armed hypersonic missiles may lead to serious escalations, given these missiles' irregular and unpredictable flight patterns.

\section{Kaynakça}

\section{Kitaplar}

Acton, J. M. (2013). Silver Bullet? Asking the right questions about Conventional Prompt Global Strike. Washington, DC: Carnegie Endowment for International Peace.

Acton, J. M. (2020). Is it a nuke: Pre-launch ambiguity and inadvertent escalation. Washington DC: Carnegie Endowment for International Peace.

Banham, R. (2015). Higher: 100 years of Boeing. San Francisco: Chronicle Books.

Bergaust, E. (2017). Wernher von Braun. Lanhan: Stackpole Books.

Builder, C. H. (2017). The Icarus syndrome: The role of air power theory in the evolution and fate of the U.S. Air Force. Oxon: Routledge.

Caston, L., Leonard, R.S., Mouton, C.A., Ohlandt, C. J. R., Moore, S.C., Conley, R.E. and Buchan, G. (2014). The Future of the U.S. Intercontinental Ballistic Missile Force. Santa Monica: RAND Corporation.

Harrison, M. (2000), New postwar branches (1): Rocketry. J. Barber ve M. Harrison (Ed.), The Soviet Defence-Industry Complex from Stalin to Khrushchev. Basingstoke: Macmillan.

Houchin II, R.F. (2006). US hypersonic research and development: The rise and fall of Dyna-Soar, 1944-1963. Oxon: Routledge. 
Hipersonik Füzeler ve Stratejik İstikrar:

Rusya-ABD İlişkileri Üzerine Bir İnceleme

Judt, T. (2005). Postwar: A history of Europe since 1945. New York: The Penguin Press.

Leggett, R. L. (1975). Additional separate views of Hon. Robert L. Legett. House Reports Vol. 1-3, Miscellaneous Reports on Public Bills III, Washington: United States Government Printing Office.

Lele, A. (2019). Disruptive technologies for the militaries and security. Singapore: Springer Nature.

Sakwa, R. (2008). Russian Politics and Society. Oxon: Routledge.

Spangenburg R. and Moser D. K. (2008). Wernher von Braun: Rocket Visionary (Revised Edition). New York: Chelsea House Publishers.

Shoumikhin, A. (2011). Nuclear weapons in Russian strategy and doctrine, S. J. Blank (Ed.), Russian Nuclear Weapons: Past, Present and Future. Carlisle: U.S. Army War College Press.

Speier, R. H., Nacouzi, G., Lee C. A ve Moore, R. M. (2017). Hypersonic Missile Nonproliferation: Hindering the Spread of a New Class of Weapons. Santa Monica: RAND Corporation.

United Nations Office for Disarmament Affairs. (2019). Hypersonic weapons: A Challenge and Opportunity for Strategic Arms Control. New York: United Nations Publication.

Walsh, D. M. (2008). The Military Balance in the Cold War: US Perceptions and Policy, 1976-85. London: Routledge.

Werrell, K. P. (1985). The Evolution of the Cruise Missile. Alabama: Air University Press.

\section{Makaleler}

Afanasyev, I. (1998). The legacy of the V-2: The First Soviet ballistic missiles. The Journal of Slavic Military Studies, 11(4), 164-174.

Bousquet, A. (2011). Complexity theory and the War on Terror: Understanding the self-organising Dynamics of leaderless jihad. Journal of International Relations and Development 15(3), 345-369. 
Claus, M. (2018). 'Russia Unveils New Strategic Delivery Systems. Jane's Intelligence Review, April 11, 2018.

Gubrud M. (2015). Going too fast: Time to ban hypersonic missile tests?. Bulletin of the Atomic Scientists. 71(5), 1-4,

Leyva, I. A. (2017). The relentless pursuit of hypersonic flight. Physics Today 70, 11(30), 31-36.

Norris, R. S. ve Kristensen H. M (2009). Nuclear U.S. and Soviet/Russian intercontinental ballistic missiles, 1959-2008, Bulletin of the Atomic Scientists, 65(1), 62-69.

Oelrich, I. (2020). Cool your jets: Some perspective on the hyping of hypersonic weapons. Bulletin of the Atomic Scientists, 76(1), 37-45.

Starchak, M. (2019). Complexities and challenges of Russia's Avangard hypersonic glide reentry vehicle. James Town (Eurasia Daily Monitor), 16(30).

The Economist (2019). Missile technology: Hypersonic boom. April 6th-12th, 6769.

The Military Balance. (1978). The United States and the Soviet Union, 78(1), 3-11.

The Military Balance. (2013). Chapter one: Conflict analysis and conflict trends, 113(1), 7-40.

Wilkening, D. (2019). Hypersonic weapons and strategic stability. Survival, 61(5), 129-148.

\section{Raporlar \& Analizler}

Acton, J. M. (2018). Hypersonic weapons explainer, April 02, 2018, 15.02.2020 tarihinde https://carnegieendowment.org/2018/04/02/hypersonic-weaponsexplainer-pub-75957 adresinden alınmıştır.

Air Force Global Strike Command. (2017). LGM-30G Minuteman III, April 16, 2017, 09.08.2020 tarihinde https://www.afgsc.af.mil/Library/FactSheets/Display/Article/630719/lgm-30g-minuteman-iii/ adresinden alınmıştır. 
Hipersonik Füzeler ve Stratejik İstikrar:

Rusya-ABD İlişkileri Üzerine Bir İnceleme

Arms Control Association. (2017). Worldwide ballistic missile inventories, 2017, December, 05.04.2020 tarihinde https://www.armscontrol.org/factsheets/ missiles adresinden alınmıştır.

Army Technology. (2013). The 10 longest range Intercontinental Ballistic Missiles (ICBMs), November 3, 2013, 10.08.2020 tarihinde https://www.armytechnology.com/features/feature-the-10-longest-range-intercontinentalballistic-missiles-icbm/ adresinden alınmıştır.

Barrie, D. (2019). Unstable at speed: Hypersonics and arms control, October 18, 2019, 18.04.2020 tarihinde https://www.iiss.org/blogs/militarybalance/2019/10/hypersonics-arms-control adresinden alınmıştır.

Department of Defense. (2018). Pentagon Nuclear Posture Review, February 2018, 24.03.2020 tarihinde https://media.defense.gov/2018/Feb/02/2001872886/1/-1/1/2018-Nuclear-Posture-Review-Final-Report.Pdf adresinden alınmıştır.

Federation of American Scientists. (2000). R-11FM / SS-1b Scud, July 12, 2000, 07.08.2020, https://fas.org/nuke/guide/russia/slbm/r-11fm.htm adresinden alınmıştır.

Freedman, L. (2013). Anti-Ballistic Missile Treaty. October 10, 2013, 12.04.2020 tarihinde https://www.britannica.com/event/Anti-Ballistic-Missile-Treaty adresinden alınmıştır.

Global Security. SS-N-33 - T3K22 Zircon/Tsirkon/3M22 rocket, 12.04.2020 tarihinde https://www.globalsecurity.org/military/world/russia/zircon.htm adresinden alınmıştır.

Johnson. R. F. (1988). Soviet applications for hypersonic vehicles. Aircraft Design, Systems and Operations Conference, 10.04.2020 tarihinde https://arc.aiaa.org/doi/ abs/10.2514/6.1988-4507 adresinden alınmıştır.

Kılıç, K. (2018). Geleceğin füzeleri saatte 6 bin kilometre hızla uçacak -1, Ağustos 18, 2018, 02.04.2020 tarihinde http://www.kokpit.aero/hakan-kilic-hipersonik-fuzeler-1 adresinden alınmıştır.

Kofman, M. (2019). Russia's Avangard hypersonic boost-glide system, January 11, 2019, 22.12.2019 tarihinde https://russianmilitaryanalysis.wordpress.com/ 
2019/01/11/ russias-avangard-hypersonic-boost-glide-system/ adresinden alınmıştır.

Leitenberg, M. (1984). Case study 3: The origin of MIRV, 09.08.2020 tarihinde https://fas.org/man/eprint/leitenberg/mirv.pdf adresinden alınmıştır.

Majumdar, D. (2018). Russia: New Kinzhal aero-ballistic missile has 3,000 km range if fired from supersonic bomber, July 18, 2018, 04.08.2020 tarihinde https://nationalinterest.org/blog/buzz/russia-new-kinzhal-aero-ballisticmissile-has-3000-km-range-if-fired-supersonic-bomber adresinden alınmıştır.

Missile Defense Advocacy. Hypersonic Weapon Basics, 03.04.2020 tarihinde https://missiledefenseadvocacy.org/missile-threat-and-proliferation/ missile-basics/hypersonic-missiles/ adresinden alınmıştır.

Missile Defense Project. (2018a). Kinzhal, March 27, 2018, 12.04 .2020 tarihinde https://missilethreat.csis.org/missile/kinzhal/ adresinden alınmıştır.

Missile Defense Project. (2018b). Missiles of Russia, June 14, 2018, 13.04.2020 tarihinde https://missilethreat.csis.org/country/russia/.COPY adresinden alınmıştır.

Missile Defense Advocacy. (1973). Soviet MIRV's, August 18, 1973, 07.08.2020 tarihinde https://www.nytimes.com/1973/08/18/archives/soviet-mirvs.html adresinden alınmıştır.

Mizokami, K. (2018). Russia shows off its latest hypersonic missile, March 12, 2018, 04.08.2020 tarihinde https://www.popularmechanics.com/military/ weapons/a19410091/russia-shows-off-its-latest-hypersonic-missile/ adresinden alınmıştır.

NASA-Glenn Research Center. Mach Number, 01.04.2020 tarihinde https://www.grc.nasa.gov/www/k-12/airplane/mach.html adresinden alınmıştır.

Sayler, K. M. (2020). Hypersonic weapons: Background and issues for Congress, March 17, 2020, 18.04.2020 tarihinde https://fas.org/sgp/crs/weapons/ R45811.pdf adresinden alınmıştır. 
Hipersonik Füzeler ve Stratejik İstikrar:

Rusya-ABD İlişkileri Üzerine Bir İnceleme

Simon, S. (2020). Hypersonic missiles are a game changer, January 2, 2020, 18.04.2020 tarihinde https://www.nytimes.com/2020/01/02/opinion/ hypersonic-missiles.html adresinden alınmıştır.

The Nuclear Threat Initiative. (2017). Is launch under attack Feasible?, August 24, 2017, 04.04.2020 tarihinde https://www.nti.org/analysis/articles/launchunder-attack-feasible/ adresinden alınmıştır.

Woolf, A. M. (2019). Conventional Prompt Global Strike and Long-Range ballistic missiles: Background and issues, August 14, 2019, 06.04.2020 tarihinde https://crsreports.congress.gov/product/pdf/R/R41464 adresinden alınmıștır.

Woolf, A. M. (2020). Russia's nuclear weapons: Doctrine, forces, and modernization, January $2, \quad 2020, \quad 14.04 .2020 \quad$ tarihinde https://crsreports.congress.gov/product/pdf/R/R45861 adresinden alınmıştır.

\section{Haber Kaynakları}

Corriere Della Sera. (2015). Vladimir Putin, Interview, June 6, 2015, 08.04.2020 tarihinde http://www.corriere.it/english/15_giugno_07/vladimir-putininterview-to-the-italian-newspaper-corriere-sera-44c5a66c-0d12-11e58612-1eda5b996824.shtml?refresh_ce-cp adresinden alınmıştır.

Egeli, S. (2020). Hayaldi Gerçek Oldu! Hipersonik Silahlar. Güvenlik Yazıları Serisi, No: 51. 07.08.2020 tarihinde https://trguvenlikportali.com/wpcontent/uploads/2020/03/HipersonikSilahlar_SitkiEgeli_v.2.pdf adresinden alınmıştır.

Federal Foreign Office. (2019). Speech by Federal Foreign Minister Heiko Maas at the Conference 2019 Capturing Technology. Rethinking Arms Control, March 15, 2019, 19.04.2020 tarihinde https://www.auswaertigesamt.de/en/newsroom/news/maas-conference-2019-capturing-technologyrethinking-arms-control/2199902 adresinden alınmıştır.

Freedberg JR., S. J. (2020). Hypersonics: Army, Navy Test Common Glide Body, March 20, 2020, 11.04.2020 tarihinde, https://breakingdefense.com/2020/ 
03/hypersonics-army-navy-test-common-glide-body/ adresinden alınmıştır.

Kremlin. (2017). Vladimir Putin's interview with Le Figaro", May 31, 2017, 10.03.2020 tarihinde http://en.kremlin.ru/events/president/news/54638 adresinden alınmıştır.

Kremlin. (2018). Presidential Address to the Federal Assembly, March 1, 2018, 14.04.2020 tarihinde http://en.kremlin.ru/events/president/news/56957 adresinden alınmıştır.

Leipold, J.D. (2015). Russia No.1 threat to US, November 10, 2015, 07.04.2020 tarihinde https://www.army.mil/article/158386 adresinden alınmıştır.

Macias. A. (2016). Putin once casually said over dinner that he could destroy America in a half-hour or less, September 13, 2016, 05.04.2020 tarihinde https://www.businessinsider.com/putin-said-he-could-destroy-the-us adresinden alınmıştır.

Macias, A. (2018). Here's what the US should do if Russia launches a nuclear attack, according to the top American nuclear commander, March 21, 2018, 01.04.2020 tarihinde https://www.cnbc.com/2018/03/21/heres-whatus-should-do-if-russia-launched-nuclear-attack-gen-hyten.html adresinden alınmıştır.

Mackinnon, A. (2019). Russia's new missiles are aimed at the U.S., March 5, 2019, 02.03.2020 tarihinde https://foreignpolicy.com/2019/03/05/russias-newmissiles-are-aimed-at-you-weapons-hypersonic-putin-united-states-inf/ adresinden alınmıştır.

Sanger, D. E. ve Kramer, A. E. (2019). U.S. Officials Suspect New Nuclear Missile in Explosion That Killed 7 Russians, August 12, 2019, 17.09.2020 tarihinde https://www.nytimes.com/2019/08/12/world/europe/russianuclear-accident-putin.html adresinden alınmıştır.

Sato, T. (2020). Interview/ Brad Roberts: Conventional strike capability by Japan good for deterrence", April 5, 2020, 07.04.2020 tarihinde http://www.asahi.com/ajw/articles/13240064 adresinden alınmıştır. 
Hipersonik Füzeler ve Stratejik İstikrar:

TASS. (2020). 20 questions with Vladimir Putin. Putin on the army and the arms race", 29.03.2020 tarihinde https://putin.tass.ru/en/ob-armii/ adresinden alınmıştır. 